\title{
Andaman Sea copepods: spatio-temporal variations in biomass and production, and role in the pelagic food web
}

\author{
Suree Satapoomin $^{1,3}{ }^{\text {, }}$ Torkel Gissel Nielsen ${ }^{2, *}$, Per Juel Hansen ${ }^{3}$ \\ ${ }^{1}$ Phuket Marine Biological Center, PO Box 60, Phuket 83000, Thailand \\ ${ }^{2}$ National Environmental Research Institute, Department of Marine Ecology, PO Box 358, Frederiksborgvej 399, \\ 4000 Roskilde, Denmark \\ ${ }^{3}$ Marine Biological Laboratory, University of Copenhagen, Strandpromenaden 5, 3000 Helsingør, Denmark
}

\begin{abstract}
Copepod community structure and productivity was investigated off the west coast of Phuket, Thailand, along transects from the shallow coastal water across the shelf break to the deep oceanic stations in the Andaman Sea. Cruises were conducted during the 2 monsoons, the calm and dry NE monsoon (November to March), and the stormy and wet SW monsoon (May to September). The copepod community was sampled with a $50 \mu \mathrm{m}$ net to include the smallest species characteristic of oligotrophic waters. The copepod community was characterized by high species diversity; highresolution analysis of species composition at the coast, the shelf break and the deep off shore stations, however, revealed no differences in species composition between areas. Small copepods, mainly cyclopoids and poecilostomatoids (dominated by Oithona spp. and Oncaea spp.), made up half of the number and ca. $25 \%$ of the copepod biomass. Despite the presence of highly dynamic internal waves at the shelf break, no response in either copepod biomass or potential prey biomass (phytoplankton and protozooplankton) was observed at the shelf break. Egg production rates of 5 calanoid species (Acrocalanus gibber, Acartia australis, Centropages furcatus, Temora discaudata, Euchaeta marinella), 1 cyclopoid (Oithona plumifera) and 1 poecilostomatoid (Oncaea venusta) were measured and compared along transects and between seasons. No spatial or seasonal patterns in biomass or egg production rates of the investigated copepods were observed. Carbon flow budgets for the 3 areas investigated suggest that the production of the copepod community in this picoplankton-dominated environment is strongly dependent on protozooplankton as prey to fuel the measured egg production rates.
\end{abstract}

KEY WORDS: Tropical copepod community $\cdot$ Calanoids $\cdot$ Cyclopoids $\cdot$ Egg production $\cdot$ Secondary production · Andaman Sea

\section{INTRODUCTION}

Copepods dominate the mesozooplankton in the oceans and play a key role in transferring primary production to higher trophic levels in all pelagic ecosystems (Verity \& Smetacek 1996). Knowledge about rates (production and grazing) is essential in the framework of understanding the flux of carbon and nutrients through the food chain. Unfortunately, most of our information on carbon fluxes in the pela- gial is based on investigations conducted in polar and temperate ecosystems. Despite the fact that tropical seas cover $42 \%$ of the world's oceans (Longhurst \& Pauly 1987), comparatively little is known about pelagic carbon and nutrient fluxes in tropical marine ecosystems.

Polar and temperate seas are characterised by pronounced seasonal fluctuations in irradiance, temperature, phytoplankton biomass and species composition, all factors which directly or indirectly influence 
growth rate and production of copepods (Kiørboe \& Nielsen 1994, Madsen et al. 2001). In comparison, tropical seas have minor seasonal fluctuations in irradiance and temperature. Studies so far carried out in tropical areas covering a gradient from eutrophic coastal waters (e.g. Chisholm \& Roff 1990a,b, Webber \& Roff 1995a, Lugomela et al. 2001) to oligotrophic deep waters (e.g. Madhupratap et al. 1996, Landry et al. 2001) suggest that tropical oceans are characterised by relatively constant phytoplankton biomass and composition. The seasonal fluctuations observed in the tropics, although relatively weak compared with higher lattitudes, are usually related to the rather variable pattern of rainfall (Chisholm \& Roff 1990b), or increased storm frequency during monsoon periods and associated upwelling events (Smith 1982, Schalk 1987, Baars et al. 1990).

In the oligotrophic tropical seas, the primary producers are often dominated by picoplankton (Li et al. 1983, Lebouteiller et al. 1992, Garrison et al. 2000) and thus not directly available to the copepods. Field studies on rates of egg production by copepods have documented that female fecundity is often limited by food availability, particularly in the tropics (Kimmerer \& McKinnon 1987, Kiørboe \& Nielsen 1994, McKinnon 1996, Hopcroft \& Roff 1998a,b, Calbet \& Augustí 1999). Thus, copepod production may potentially be strongly food limited in tropical oligotrophic seas. Consequently, the microbial food web may play a significant role by making the primary producers available to higher trophic levels, thereby compensating for the very low concentrations of phytoplankton prey. Recently large multidisciplinary research programmes have been directed to investigations of the dynamics of the tropical Arabian Sea (Burkill et al. 1993, Krishnaswami \& Nair 1996, Smith et al. 1998). These studies have significantly improved our knowledge and understanding of the seasonal and spatial variability of the oceanography and biogeochemical cycling of tropical oceans driven by monsonal forcing, like the Andaman Sea.

The Andaman Sea off the western coast of Thailand is a very important fishing ground providing ca. $1 / 3$ of the annual marine fish catch in Thailand (Fisheries Statistics of Thailand, Anon 1997). Knowledge about the food web that supports this fish stock is, however, very limited. Most of the research in plankton ecology in Thai waters has been focused on the coastal ecosystem (Boonruang 1985, Sündstrøm et al. 1987, Janekarn \& Hylleberg 1989). Studies on copepods from Thai coastal waters have been restricted to (1) species composition and abundance (Boonruang 1985, Satapoomin 1999, Satapoomin \& Pornchai 2002), and (2) seasonal and temporal variability in the community structure of copepods. Studies of copepod production are completely lacking.
The oceanography and pelagic community structure at the shelf break front in the Andaman Sea has previously only been considered by Kiørboe et al. (1991). During a transect study across the shelf break, they measured a 3-fold increase in primary production and much higher abundance of tunas, marine mammals and sea birds at the shelf break compared to the coastal and shelf areas. These observations led to the hypothesis that the shelf break was a very important site of primary and secondary production, and thus an area in which pelagic fisheries could be developed (Kiørboe et al. 1991). This hypothesis was a central part of the scientific background for the project 'Pelagic Andaman Sea structure, function and productivity with particular emphasis on an access of potential fisheries resources' under a Thai-Danish scientific cooperation program. The present investigation on community structure, biomass and productivity of the Andaman Sea copepods was part of this program, which was initiated in 1996 at Phuket Marine Biological Center.

We investigated spatial and temporal variability in biomass, community structure, production and the trophic role of the Andaman Sea copepods along transects from the coastal shallow water across the shelf to the deep oceanic areas. The emphasis was on the role of the shelf break area in the secondary production of the Andaman Sea.

\section{MATERIALS AND METHODS}

Study area. The investigation was conducted in the Andaman Sea on the western coast of Thailand during 4 cruises in 1996 and 1997. Two cruises were conducted each year representing the 2 monsoon seasons, northeast (NE) and southwest (SW). Cruises in 1996 were carried out during the periods of March 11 to 27 (NE monsoon), and August 15 to 29 (SW monsoon). Cruises in 1997 were carried out from February 11 to 27 (NE monsoon), and August 26 to 28 and September 1 to 11 (SW monsoon). These cruises will be referred to as cruises NE-96, SW-96, NE-97 and SW-97, respectively.

Sampling was carried out along transects perpendicular to the shoreline from the coast, across the shelf, to the offshore area, with approximately 12 stations on each transect (Fig. 1). The distance between stations was $5 \mathrm{n}$ miles, except on the shelf break and the deeper outermost stations where the resolution was 2.5 and $10 \mathrm{n}$ miles, respectively. The total number of stations visited per cruise varied due to the interference of bad weather. At all stations visited, profiles of salinity and temperature were taken and samples for phytoand zooplankton biomass were collected, while rate 


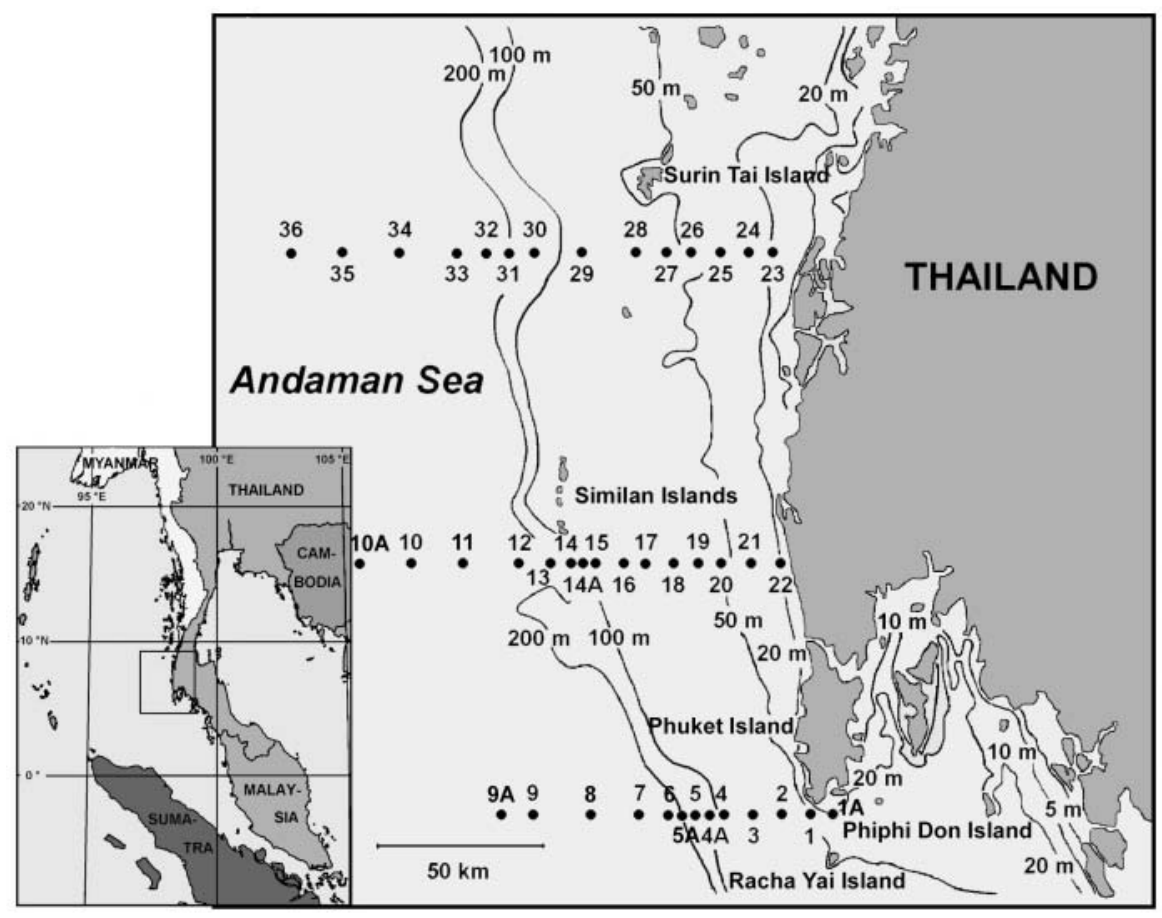

Fig. 1. Positions of stations and transects investigated during the 3 cruises in the Andaman Sea off the western coast of Thailand. The southern transect is \#1, the northern is \# 3

measurements were conducted with lower spatial resolution, approximately at every second station.

Detailed information on the oceanography and plankton community structure from the 2 cruises in 1996 is presented in Nielsen et al. (2004 this issue) and Munk et al. (2004 this issue). Since no experiments on copepods egg production were performed during Cruise NE-96, this paper only presents data collected on the last 3 cruises.

Hydrography. At each station, the vertical structure of the water column was characterized using a SeaBird SBE 25-01 Sealogger CTD equipped with a Chelsea fluorometer. At all stations, the CTD casts were repeated 5 times in a connected series from the surface to a depth of ca. $150 \mathrm{~m}$ at deep stations, and $5 \mathrm{~m}$ above sea bottom at shallow stations, in order to describe the dynamic pycnocline (for further details see Nielsen et al. 2004). The downcast sequence was averaged every $0.3 \mathrm{~m}$ for presentation of profiles.

Copepod food. Total chl a: At each station, 41 of water were taken for the measurement of total chl $a$ concentration at 5 depths covering the upper $100 \mathrm{~m}$ of the water column. The phytoplankton were collected on a GF/C filter by filtration. Filters were then homogenized and extracted in $90 \%$ acetone for $6 \mathrm{~h}$ in darkness. Extractions were analyzed on a spectrophotometer and the total chl a concentration was calculated using the equation of Jeffrey \& Humphrey (1975). The relative profiles of chlorophyll fluorescence values were converted to chl a from a linear regression between the fluorescence (fluo) and spectrophotometric measurements of chl a covering all transects (chl a = fluo/0.6506-0.012, $\mathrm{r}^{2}=0.83, \mathrm{n}=$ 113). Chl a was converted to carbon applying a general conversion factor of 54.5 , or 74 or 35 for the surface and pycnocline respectively (Nielsen et al. 2004).

Fractionated chl a: On Cruise NE-97, the size distribution of phytoplankton was investigated at the surface (5 $\mathrm{m}$ depth) and at the depth of maximum fluorescence (FM). Fluorescence was measured in the $0.7-1,1-5,5-10,10-50$ and $>50 \mu \mathrm{m}$ size fractions at all stations where copepod production was measured. Triplicate samples (280 ml) were filtered using $0.7 \mu \mathrm{m}$ GF/F filters, 1 and $5 \mu \mathrm{m}$ Poretics filters and 10 and $50 \mu \mathrm{m}$ Nitex-filters. The filters were extracted in $5 \mathrm{ml}$ of $95 \%$ ethanol for $6 \mathrm{~h}$ and measured on a 10-AU Turner Fluorometer. The fluorescence was calibrated against a purified chl a standard.

Protozooplankton (ciliates and heterotrophic dinoflagellates): The focus in the present study was on ciliates and heterotrophic dinoflagellates $(>10 \mu \mathrm{m})$; i.e. heterotrophic flagellates $<10 \mu \mathrm{m}$ were not quantified. Samples were taken from 3 depths (5 m, FM, and $100 \mathrm{~m}$ ). Water samples were gently poured into a $300 \mathrm{ml}$ bottle and fixed with $2 \%$ Lugols (final concentration). Identification and enumeration of the organisms were done after overnight sedimentation using an Olympus CK-2 inverted microscope. Cell volumes were estimated from linear dimensions using simple volumetric formulae, and carbon biomass was calculated using a conversion factor of $12 \mathrm{pg} \mathrm{C} \mathrm{m}^{-3}$ (Hansen et al. 1997).

Copepod community. Samples for mesozooplankton abundance and biomass were taken by vertical net hauls with a $200 \mu \mathrm{m}$ WP-2 and a net with $50 \mu \mathrm{m}$ mesh. On Cruise SW-97, a submersible plankton pump (Grundfos SP16-2) equipped with a $50 \mu \mathrm{m}$ net was used. A General Oceanic flow meter was mounted across the net mouth to measure the volume filtered. Samples were taken from bottom to surface at the shallow coastal stations or from $100 \mathrm{~m}$ to surface at the deeper stations. Nets were retrieved at ca. $12 \mathrm{~m} \mathrm{~min}^{-1}$. To compensate for the difference in sampling gear, a net-pump inter-calibration was performed. At Stn 12, 5 replicated samples were taken from $50 \mathrm{~m}$ to the sur- 
Table 1. Length to carbon-weight (L-W) equations applied for biomass calculation of different copepod species. Sources: (1) Satapoomin (1999a); (2) Kiørboe \& Sabatini (1994); (3) Hygum et al. (2000)

\begin{tabular}{|lcc|}
\hline Taxon & L-W regression & Source \\
\hline Acartia australis & Eqn of C. furcatus & $(1)$ \\
Acrocalanus gibber & $9.66 \times 10^{-7} \mathrm{~L}^{2.26}$ & $(1)$ \\
Centropages furcatus & $2.11 \times 10^{-11} \mathrm{~L}^{3.82}$ & $(1)$ \\
Euchaeta marinella & $1.15 \times 10^{-11} \mathrm{~L}^{3.82}$ & $(1)$ \\
Temora discaudata & $2.6 \times 10^{-10} \mathrm{~L}^{3.55}$ & $(1)$ \\
Calanoids & As A. gibber & $(1)$ \\
Corycaeus spp. & $4.98 \times 10^{-6} \mathrm{~L}^{1.99}$ & $(1)$ \\
Oithona similes & As Oithona spp. & $(2)$ \\
Oithona spp. & $9.47 \times 10^{-7} \mathrm{~L}^{2.16}$ & $(2)$ \\
Oncaea venusta & As Oncaea spp. & $(1)$ \\
Oncaea spp. & $2.51 \times 10^{-8} \mathrm{~L}^{2.9}$ & $(1)$ \\
Other cyclopoid copepods & As Corycaeus spp. & $(1)$ \\
(Sappharina and Copelia) & $8.5 \times 110^{-4} \mathrm{~L}^{1.03}$ & $(1)$ \\
Harpacticoids & $4.17 \times 10^{-6} \mathrm{~L}^{2.03}$ & $(3)$ \\
Nauplii & & \\
\hline
\end{tabular}

face by each set of gears and the size distribution of copepods compared.

Copepod biomass: Samples were fixed in borax buffered formalin ( $2 \%$ final concentration). Dependent on density, subsamples ( $1 / 32$ of total) were counted until approximately 400 copepods were sorted and identified to order, genera or species level. Each category of copepods was measured (cephalothorax length), except for total length of nauplii and harpacticoids. The lengths were later converted to carbon from relevant length-weight regressions (Table 1).

Species composition: The focus of the present investigation was to compare different functional groups of copepods. Therefore, we generally separated the copepods into 4 major groups: calanoids, cyclopoids, harpacticoids and nauplii. Although Oncaea spp. have recently been transferred from the Cyclopidea to the order Poecilostomatoida (Ho 1991), we have presented them together. Species composition was studied, how- ever, at higher taxonomic resolution at Stns 18, 14 and 10 on the middle transect of each cruise representing coastal, shelf front and offshore areas, respectively. Cluster analysis was applied to determine the community structure in the 3 different areas.

Patchiness test: To investigate the plankton patchiness between stations, a grid of 12 stations was laid in the vicinity of Stns 14 and 14a. Two new stations were selected between those 2 stations and 2 parallel transects were sampled on each side of the main transect, making the resolution in space only $500 \mathrm{~m}$. Samples were taken from $100 \mathrm{~m}$ depth to surface by a Grundfos-pump equipped with a $50 \mu \mathrm{m}$ mesh cod-end. Specimens were processed to the same level as for the routine copepod biomass samples.

Copepod production. Egg production by free spawning species: Copepods for the egg production experiments were collected from vertical tows starting from just below the pycnocline using the 50 and $200 \mu \mathrm{m}$ plankton nets. On deck, the contents of the cod ends were diluted in a 251 bucket containing surface seawater and brought directly to the laboratory. Within the next few hours, females were sorted, and 2 to 6 females were placed in each of 3 to 6 glass jars of $500 \mathrm{ml}$ for each species. The females were incubated at $25^{\circ} \mathrm{C}$ for 6 to $10 \mathrm{~h}$, after which the spawned eggs were counted and female lengths and egg diameters were measured (Table 2).

Egg production by egg carrying species: Egg production rates were measured for representatives of 3 dominant groups of egg carrying copepods: Oncaeidae, Oncaea vensuta; Oithonidae, Oithona plumifera; and Euchaetidae, Euchaeta marinella. Females with egg sacs were placed individually in tissue culture plates (NUNCTM Multi wells) containing $2 \mathrm{ml}$ of $50 \mu \mathrm{m}$ filtered surface water and incubated at $25 \pm 1^{\circ} \mathrm{C}$. The wells were inspected and temperature recorded at 3 to $6 \mathrm{~h}$ intervals. Hatching percentage was calculated from number of clutches hatched divided by the number of females incubated. Hatching rate was calculated from

Table 2. Size $(\mu \mathrm{m})$, size range $(\mu \mathrm{m})$, number of specimens $(\mathrm{n})$ and carbon content $\left(\mu \mathrm{g} \mathrm{C}\right.$ ind.$\left.^{-1}\right)$ of female copepods and their eggs from egg production experiments

\begin{tabular}{|c|c|c|c|c|c|c|c|c|}
\hline & \multicolumn{4}{|c|}{ Female } & \multicolumn{3}{|c|}{ Egg } & \multirow{3}{*}{$\begin{array}{c}\text { Carbon } \\
\text { content }\end{array}$} \\
\hline & \multicolumn{2}{|c|}{ Length } & \multirow[t]{2}{*}{$\mathrm{n}$} & \multirow{2}{*}{$\begin{array}{l}\text { Carbon } \\
\text { content }\end{array}$} & \multicolumn{2}{|c|}{ Diameter } & \multirow[t]{2}{*}{$\mathrm{n}$} & \\
\hline & Mean \pm SE & Range & & & Mean \pm SE & Range & & \\
\hline Acartia australis & $1132 \pm 2.0$ & $900-1240$ & 489 & 9.77 & $81 \pm 0.6$ & $75-85$ & 19 & 0.039 \\
\hline Acrocalanus gibber & $898 \pm 2.1$ & $700-1100$ & 801 & 4.56 & $99 \pm 0.6$ & $90-110$ & 55 & 0.071 \\
\hline Centropages furcatus & $1125 \pm 1.9$ & $1000-1260$ & 465 & 9.54 & $79 \pm 0.4$ & $75-90$ & 55 & 0.036 \\
\hline Euchaeta marinella & $1697 \pm 13.0$ & $1520-1880$ & 240 & 25.01 & $245 \pm 1.7$ & $225-260$ & 29 & 1.081 \\
\hline Oncaea venusta & $724 \pm 1.4$ & $600-820$ & 712 & 4.93 & $51 \pm 0.8$ & $35-60$ & 44 & 0.010 \\
\hline Oithona similis & $559 \pm 1.7$ & $460-680$ & 220 & 0.81 & $62 \pm 0.7$ & $55-75$ & 54 & 0.017 \\
\hline Temora discaudata & $1104 \pm 2.5$ & $880-1260$ & 630 & 16.50 & $71 \pm 0.5$ & $63-75$ & 42 & 0.027 \\
\hline
\end{tabular}


the slope of a linear regression between the incubation time and the cumulative hatching percentage. Hatching time (HT) is defined as the time required to reach $100 \%$ hatching, as predicted from these regressions.

Egg production rates of the egg carrying species were then calculated from the egg-hatching rate and the in situ egg:female ratio of the population (i.e. including loose sacs and females nor carrying egg sacs) from the $50 \mu \mathrm{m}$ net samples. For Oncaea venusta, which carry 2 very dense egg sacs with $>50$ eggs sac ${ }^{-1}$, it was impossible to count the eggs in the samples. We therefore determined egg number from the number of hatched nauplii. For this purpose, 24 to 48 females with
2 egg sacs were transferred individually into $2 \mathrm{ml}$ of seawater in NUNC ${ }^{\mathrm{TM}}$ multiwell at each station.

The egg production rates $\left(E P\right.$; egg fem ${ }^{-1} d^{-1}$ ) of the egg carrying species were calculated from the in situ ratio of egg:female ratio and hatching rate (HR):

$$
\mathrm{EP}=(\text { egg:female }) \times \mathrm{HR}
$$

Carbon-specific egg production rates (SEP) were calculated according to the equation:

$$
\mathrm{SEP}=\mathrm{EP} \times\left(C_{\mathrm{e}} / C_{\mathrm{f}}\right)
$$

where: $C_{\mathrm{e}}=$ egg carbon calculated from egg volume and a volume to carbon ratio of $0.14 \mathrm{pg} \mathrm{C}^{-3}$

Table 3. Position, depth $(\mathrm{m})$ and averaged water column temperature from surface to bottom or $100 \mathrm{~m}(\mathrm{mean} \pm \mathrm{SE}, \mathrm{n})$ of the

\begin{tabular}{|c|c|c|c|c|c|}
\hline Stn & Longitude & Depth & SW-96 & NE-97 & SW-97 \\
\hline $1 \mathrm{a}$ & 98.20 & 32 & & $28.95 \pm 0.01,83$ & $27.98 \pm 0.06,28$ \\
\hline 1 & 98.15 & 60 & $28.72 \pm 001,187$ & $28.46 \pm 0.06,185$ & $26.82 \pm 0.19,59$ \\
\hline 2 & 98.10 & 72 & $28.26 \pm 0.06,235$ & $27.63 \pm 0.13,235$ & \\
\hline 3 & 98.05 & 69 & $28.32 \pm 0.06,218$ & & $27.33 \pm 0.06,471$ \\
\hline 4 & 98.00 & 69 & $28.54 \pm 0.03,118$ & $28.03 \pm 0.10,205$ & \\
\hline $4 \mathrm{a}$ & 97.58 & 133 & & $26.23 \pm 0.15,328$ & $26.85 \pm 0.15,101$ \\
\hline 5 & 97.55 & 172 & $27.00 \pm 0.13,331$ & $25.60 \pm 0.18,330$ & $28.38 \pm 0.05,101$ \\
\hline $5 a$ & 97.53 & 188 & & & $25.3 \pm 0.4,100$ \\
\hline 6 & 97.50 & 253 & $26.73 \pm 0.16,331$ & $26.65 \pm 0.13,327$ & $26.66 \pm 0.27$ \\
\hline 7 & 97.44 & 300 & $27.56 \pm 0.10,332$ & & \\
\hline 8 & 97.35 & 424 & $27.56 \pm 0.10,329$ & $24.87 \pm 0.16,333$ & $26.41 \pm 0.31,101$ \\
\hline 9 & 97.41 & 437 & $26.42 \pm 0.14,330$ & & \\
\hline $9 a$ & 97.20 & 491 & & & $25.94 \pm 0.28,101$ \\
\hline 22 & 98.13 & 18 & $29.22 \pm 0.01,62$ & $28.84 \pm 0.03,53$ & $29.08 \pm 0.11,18$ \\
\hline 21 & 98.08 & 38 & $29.28 \pm 0.02,126$ & $28.68 \pm 0.04,117$ & \\
\hline 20 & 98.03 & 58 & $29.09 \pm 0.02,186$ & $28.06 \pm 0.08,154$ & $28.53 \pm 0.08,52$ \\
\hline 18 & 97.53 & 68 & $28.35 \pm 0.14,225$ & $26.76 \pm 0.14,225$ & \\
\hline 19 & 97.58 & 77 & $28.09 \pm 0.14,253$ & $27.28 \pm 1.35,237$ & \\
\hline 17 & 97.48 & 80 & $27.59 \pm 0.15,256$ & $27.50 \pm 0.10,235$ & $27.24 \pm 0.23,77$ \\
\hline 15 & 97.38 & 87 & $27.21 \pm 0.15,287$ & $25.24 \pm 0.15,287$ & $26.66 \pm 0.27,82$ \\
\hline 16 & 97.43 & 87 & $27.31 \pm 0.15,279$ & $25.31 \pm 0.16,268$ & $26.96 \pm 0.26,78$ \\
\hline $14 a$ & 97.34 & 110 & & $28.08 \pm 0.07,165$ & $25.87 \pm 0.33,101$ \\
\hline 14 & 97.33 & 194 & $26.73 \pm 0.14,333$ & $26.45 \pm 0.12,332$ & $27.72 \pm 0.12,101$ \\
\hline 13 & 97.28 & 279 & $26.42 \pm 0.16,332$ & $24.74 \pm 0.15,332$ & $26.72 \pm 0.26,101$ \\
\hline 12 & 97.23 & 355 & $28.10 \pm 0.06,331$ & $25.57 \pm 0.15,332$ & \\
\hline 11 & 97.13 & 413 & $28.40 \pm 0.03,251$ & $26.43 \pm 0.13,332$ & $26.12 \pm 0.30,101$ \\
\hline 10 & 97.03 & 460 & $27.37 \pm 0.10,333$ & $25.31 \pm 0.15,323$ & \\
\hline $10 \mathrm{a}$ & 96.52 & 483 & & $26.42 \pm 0.12,323$ & $27.10 \pm 0.21,101$ \\
\hline 23 & 98.10 & 23 & & $28.57 \pm 0.01,67$ & \\
\hline 24 & 98.06 & 35 & $28.89 \pm 0.001,128$ & $28.06 \pm 0.05,104$ & \\
\hline 25 & 98.01 & 46 & & $27.65 \pm 0.07,138$ & \\
\hline 26 & 97.56 & 56 & $28.98 \pm 0.003,52$ & $26.62 \pm 0.13,181$ & \\
\hline 27 & 97.51 & 68 & & $26.96 \pm 0.12,208$ & \\
\hline 28 & 97.46 & 79 & & $25.42 \pm 0.15,248$ & \\
\hline 29 & 97.36 & 85 & & $25.55 \pm 0.16,266$ & \\
\hline 30 & 97.25 & 163 & & $25.10 \pm 0.13,330$ & \\
\hline 31 & 97.20 & 203 & & $22.75 \pm 0.24,330$ & \\
\hline 32 & 97.16 & 250 & & $23.81 \pm 0.20,329$ & \\
\hline 33 & 97.10 & 280 & & $25.34 \pm 0.15,330$ & \\
\hline 34 & 97.01 & 380 & & $27.15 \pm 0.06,326$ & \\
\hline 35 & 96.51 & 380 & & $25.57 \pm 0.15,326$ & \\
\hline 36 & 96.41 & 400 & & $27.28 \pm 0.07,300$ & \\
\hline
\end{tabular}
stations of 3 cruises in the Andaman Sea 
(Huntley \& Lopez 1992) and $C_{\mathrm{f}}=$ female carbon biomass estimated from length-carbon regressions (Table 1).

Copepod production was then calculated by multiplying biomass with SEP, assuming that SEP of adult females equals the growth rates of the juvenile stages (Berggreen et al. 1988). For those species in which egg production was not measured, the average SEP for the relevant taxonomical group was applied. In the case of nauplii, the average SEP of all groups was used. The egg production rates of all species investigated were recalculated to in situ temperature conditions using the mean temperature from surface to bottom or $100 \mathrm{~m}$ at each station (Table 3), and a $Q_{10}$ value of 2.8 (Hansen et al. 1997).
Depth integration. All biological data are presented per $\mathrm{m}^{2}$. The biomass of the discrete samples of microprotozooplankton ( 3 to 5 depths per station) and chl a fluorescence (50 to 200 measurements) were transformed by trapezoidal integration to $100 \mathrm{~m}$, or the bottom at the shallower stations. The copepod communities were integrated during sampling from the bottom at the shallower and the upper $100 \mathrm{~m}$ at the off-shelf station. The grazing and production rates were corrected according to average temperature in the water column sampled using a $Q_{10}$ of 2.8 (Hansen et al. 1997).

Data analysis. Correlations were calculated based on the raw data set, while 1-way ANOVA and cluster analysis were based on $\log (x+1)$ transformed data. In general, a significance level of $5 \%$ was used.

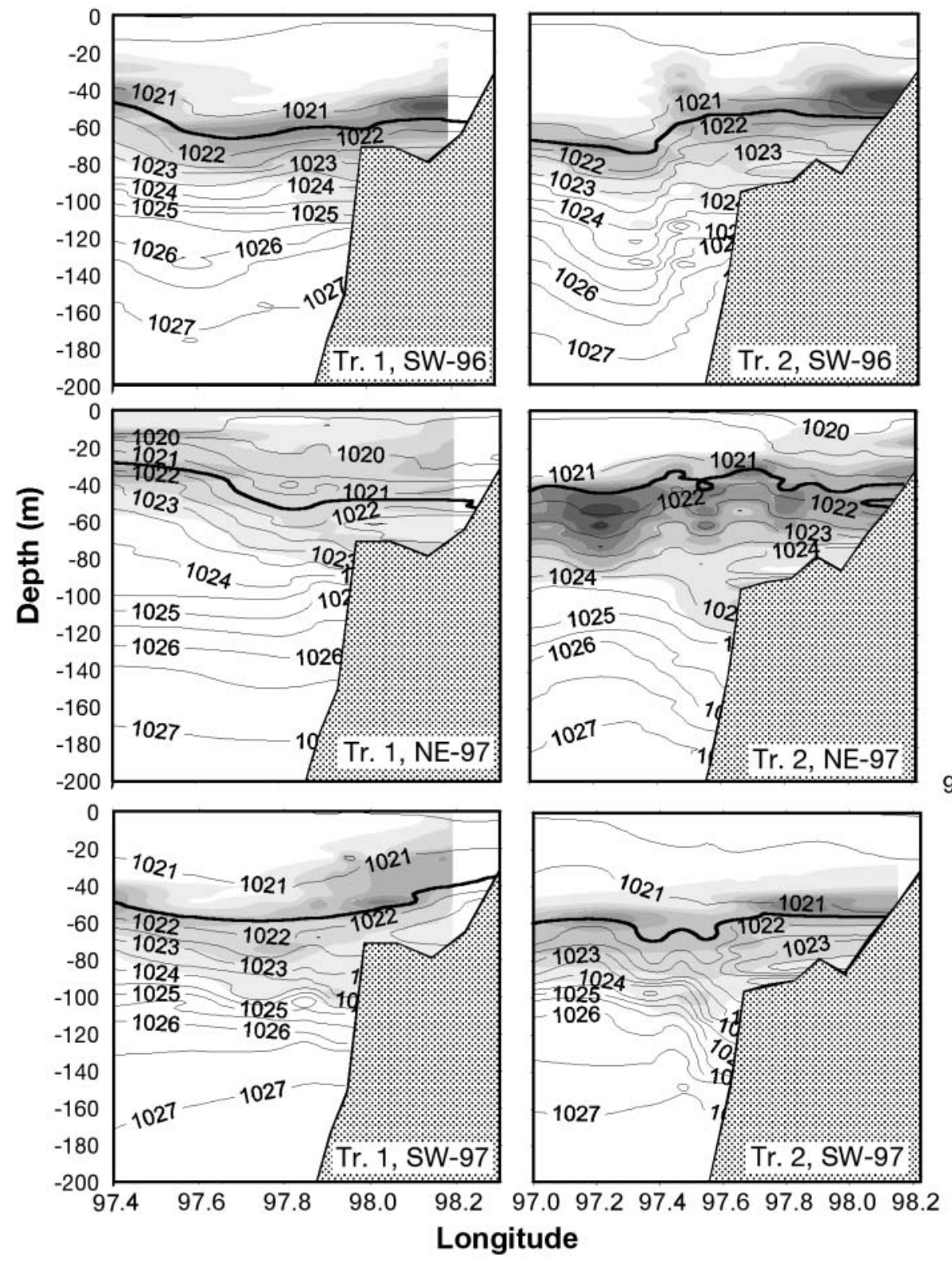

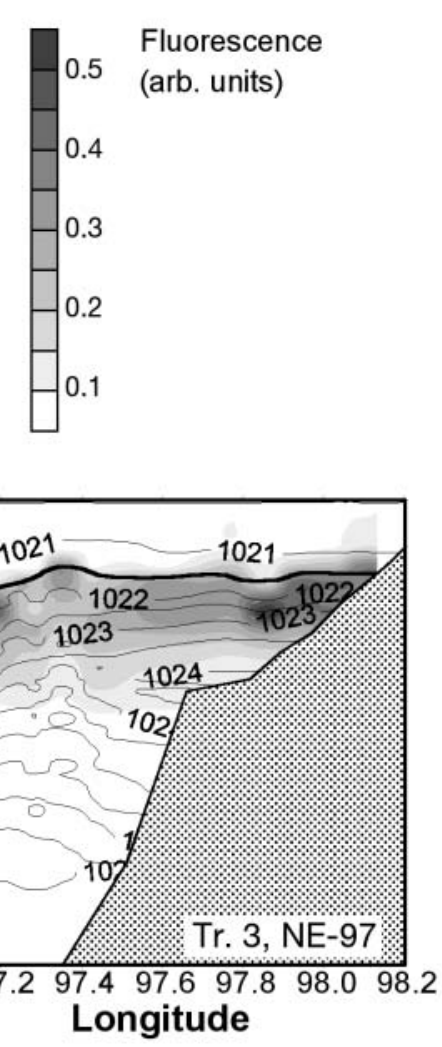

Fig. 2. Vertical profiles of chl a fluorescence (shading) and water density (isolines) along the transects on Andaman Sea cruises during 1996 and 1997 
SW-96
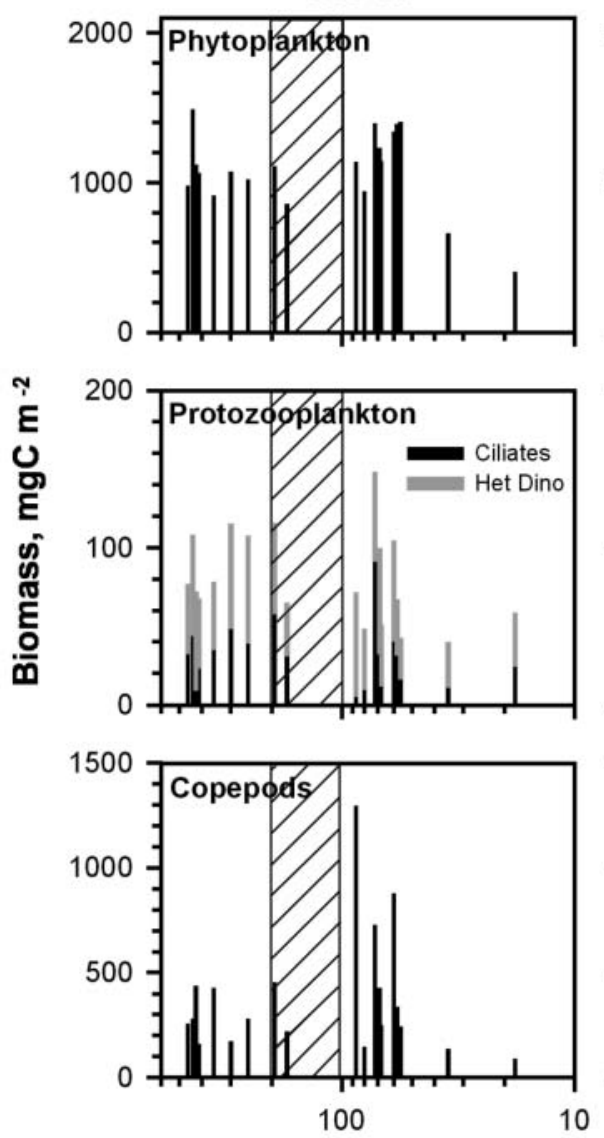

NE-97
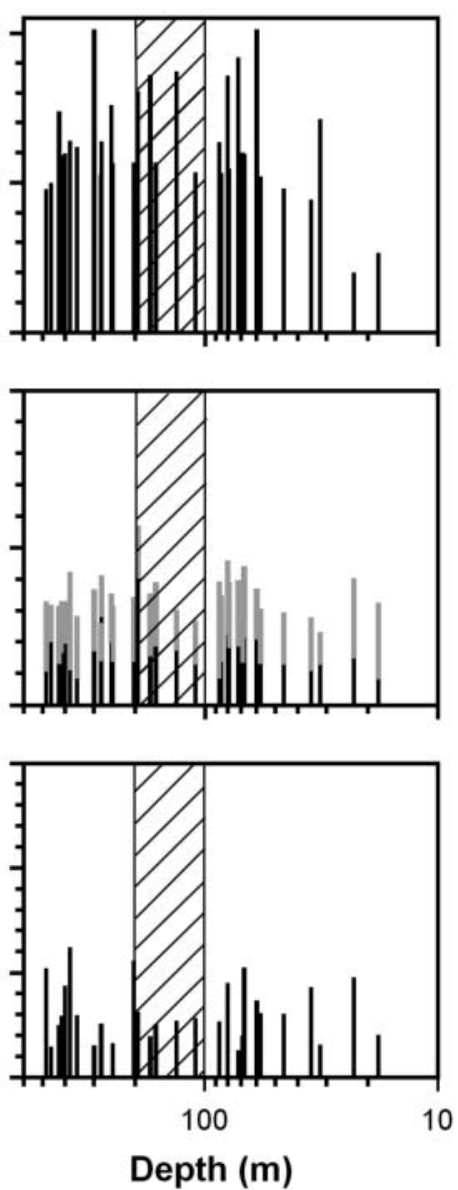

SW-97
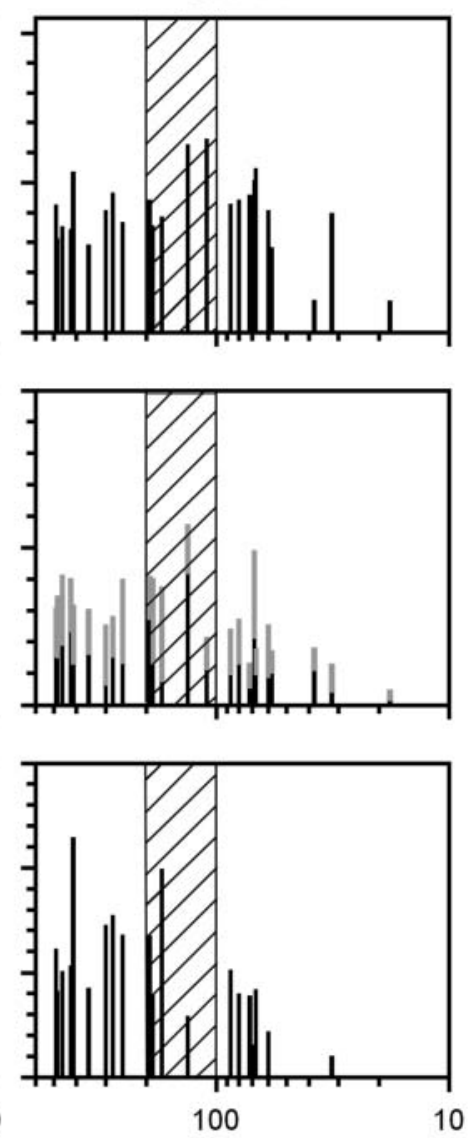

Fig. 3. Integrated biomass $\left(\mathrm{mg} \mathrm{C} \mathrm{m}^{-2}\right.$ ) of phytoplankton, microprotozooplankton (ciliates and heterotrophic dinoflagellate) and total copepods in the upper $100 \mathrm{~m}$ during Andaman Sea cruises during 1996 and 1997 . Hatched area indicates the upper shelf break at 100 to $200 \mathrm{~m}$

\section{RESULTS}

\section{Summary of hydrography}

The water column at the coastal stations on the shore side of the mid-shelf front was vertically mixed, while the deeper stations were strongly stratified (Fig. 2). The surface temperature ranged from 28 to $30^{\circ} \mathrm{C}$, and the salinity ranged from 31.3 and $33.6 \mathrm{psu}$. The pycnocline (here defined as the isopycnal of $1021.5 \mathrm{~kg} \mathrm{~m}^{-3}$ ) was located between 30 and $80 \mathrm{~m}$. The depth of the upper mixed layer changed seasonally. During the NE monsoon the pycnocline was located at $40 \mathrm{~m}$, while the increased wind stress during the SW monsoon eroded the pycnocline down to $60 \mathrm{~m}$. Below the pycnocline, water temperature decreased to $14^{\circ} \mathrm{C}$ and salinity increased to $34.8 \mathrm{psu}$. Since no differences between transects were observed, we will focus on seasonal and inter-annual variations.

\section{Phytoplankton}

A subsurface fluorescence maximum occurred whenever a pycnocline was present. The fluorescence maximum covered the depth strata 40 to $100 \mathrm{~m}$, with peak values located in the pycnocline. The surface layer was depleted in nitrogen (Nielsen et al. 2004). During the NE monsoon, the highest fluorescence values were observed at ca. $40 \mathrm{~m}$ in all transects, while the highest fluorescence during SW monsoon was located deeper, according to the mixing of the surface layer down to 60-70 m (Fig. 2). Chl a concentrations in the surface water $\left(5 \mathrm{~m}\right.$ ) averaged $0.19 \pm 0.02 \mu \mathrm{g} \mathrm{l}^{-1}$ (or $\left.9.8 \pm 0.9 \mu \mathrm{g} \mathrm{C}^{-1}\right)(\mathrm{n}=82)$ for all cruises, and averaged $0.40 \pm 0.02 \mu \mathrm{g} \mathrm{l}^{-1}$ (or $\left.20.1 \pm 0.9 \mu \mathrm{g} \mathrm{Cl}^{-1}\right)(\mathrm{n}=82)$ in the FM. Depth-integrated phytoplankton biomass (calculated from the integrated chlorophyll value) ranged from 203 to $2011 \mathrm{mg} \mathrm{C} \mathrm{m}^{-2}$, averaging $1052 \pm 39 \mathrm{mg} \mathrm{C}$ $\mathrm{m}^{-2}(\mathrm{n}=82)$ (Fig. 3). There was no statistical difference 
in phytoplankton biomass between season (Cruise SW-96 vs NE-97, p > 0.1) or year (SW-96 vs SW-97, $\mathrm{p}>0.1$ ).

Fractionated chl a was only measured on Cruise NE-97. Small cells $(<10 \mu \mathrm{m})$ dominated the phytoplankton community, contributing $68.0 \pm 3.4 \%$ at $5 \mathrm{~m}$ and $89.4 \pm 1.5 \%$ at FM. The lower contribution of small phytoplankton in the $5 \mathrm{~m}$ samples was caused by the occurrence of the large $(>50 \mu \mathrm{m})$ colonial cyanobacteria Trichodesmium spp., in the surface water (Fig. 4).

\section{Protozooplankton}

The protozooplankton was dominated by heterotrophic dinoflagellates and ciliates. The 2 groups contributed equally to biomass, which averaged $1.1 \pm$ $0.08 \mu \mathrm{g} \mathrm{Cl}^{-1}$ in surface water $(\mathrm{n}=82$ range 0.2 to $5.6 \mu \mathrm{g}$ $\mathrm{C}^{-1}$ ) and $1.1 \pm 0.08 \mu \mathrm{g} \mathrm{Cl}^{-1}$ at the $\mathrm{FM}(\mathrm{n}=81$ range 0.2 to $5.6 \mu \mathrm{g} \mathrm{C}^{-1}$ ). Depth-integrated values for total ciliates and dinoflagellates ranged from 8.4 to $146.9 \mathrm{mg} \mathrm{C}$ $\mathrm{m}^{-2}$, with a mean of $66.9 \pm 2.6 \mathrm{mg} \mathrm{C} \mathrm{m}^{-2}, \mathrm{n}=82$ (Fig 3). Comparison of the integrated protozooplankton biomass showed no inter-annual difference ( $p>0.2)$. There was also no difference between Cruises SW-96 and NE-97, but biomass for Cruise NE-97 was significantly higher than for Cruise SW-97 in the same year $(\mathrm{p}<0.05)$

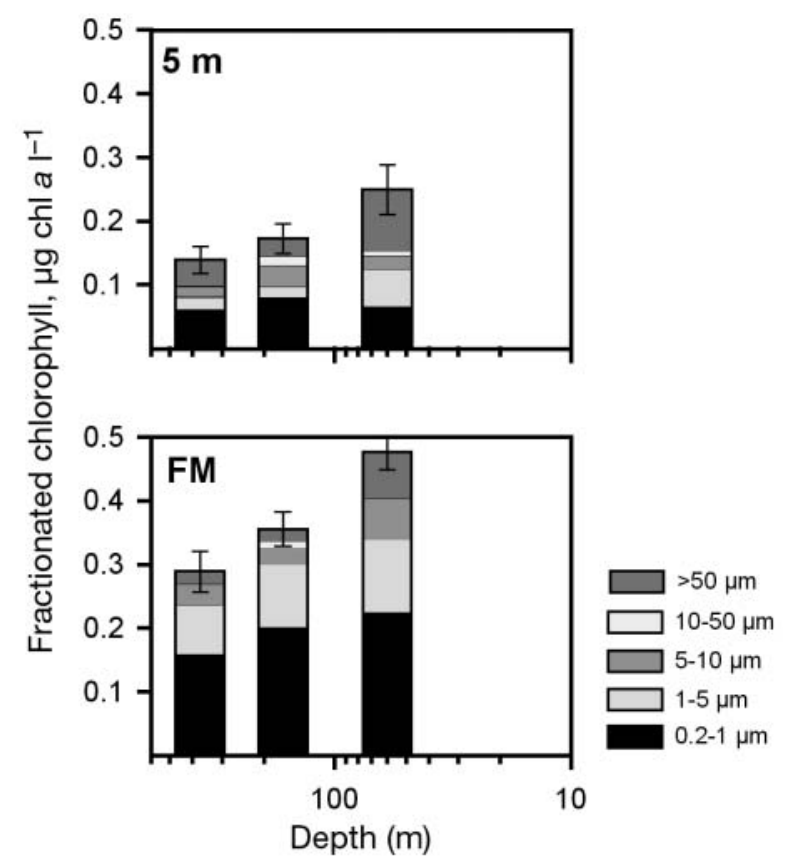

Fig. 4. Fractionated chl a $\left(\mu \mathrm{g} \mathrm{chl} \mathrm{a}^{-1}\right)$ at 2 depths in the coastal, upper shelf break and the offshore stations investigated during Cruise NE-97

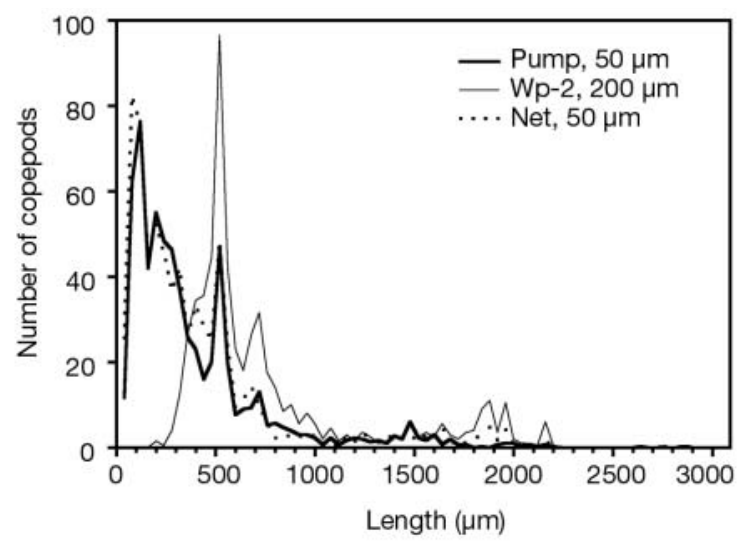

Fig. 5. Copepod size-spectra from different sampling gear (plankton net and submersible pump) and mesh sizes (50 and $200 \mu \mathrm{m})$ at Stn 12 on Cruise SW-97

\section{Gear calibration}

The $50 \mu \mathrm{m}$ plankton net and the pump gave the same size distribution of the copepod community (Fig. 5). However, the $200 \mu \mathrm{m}$ net severely undersampled specimens smaller than $400 \mu \mathrm{m}$ total length. The copepod biomass $\left(\mathrm{mg} \mathrm{C} \mathrm{m}^{-3}\right.$ ) estimated from $50 \mu \mathrm{m}$ tows was correlated with copepod biomass estimated using the pump with a $50 \mu \mathrm{m}$ cod-end; $\mathrm{r}^{2}=$ 0.69). However, the net tows caught 3.6 times more biomass than the pump. From the calibration, the pump samples were corrected according to the factor obtained from the regression between the pump and the $50 \mu \mathrm{m}$ net collections. The size spectra of copepods collected by the $50 \mu \mathrm{m}$ net covered a range from small nauplii $(40 \mu \mathrm{m})$ to the adult stages of most copepod species, while the $200 \mu \mathrm{m}$ net missed most of the naupliar stages (Fig. 5). Because of our interest in small taxa, only samples taken with the $50 \mu \mathrm{m}$ screen, plankton net and pump are considered in the following sections.

\section{Spatial variation \\ Patchiness test}

The variability of sampling between stations was evaluated for copepod biomass data from 12 samples at the sub-stations. The results showed no difference among the 3 replicates or among the sub-stations $(p>0.5)$. Because the test was performed in the most hydrodynamically variable area (at the shelf break), the results suggest that a higher spatial resolution would not provide a different pattern than the observed one. 


\section{Abundance}

The zooplankton community was dominated by copepods. Other important groups were appendicularians, thaliacean salps and chaetognaths. Among the copepods, no statistical differences were found between coastal and offshore areas during Cruises SW-96 and NE-97 ( $p>0.1$ ). However, the total copepod abundance during Cruise SW-97 was higher in the coastal area compared to the shelf and offshore areas $(p<0.05)$ due to the higher abundance of cyclopoid copepods.

On the middle transect of each cruise, where the copepod species composition was analyzed to a higher taxonomic level (Table 4) and subjected to cluster analysis, no distinct assemblages were found in the 3 defined areas on any of the cruises (Fig. 6). However, the dendrogram showed a clear separation of Cruise SW-97 from the SW-96 and NE-97 cruises.

Due to the general similarity in species composition throughout the study area during this investigation, the copepods were split into 4 major groups (calanoids, cyclopoids, here including the poecilostomatoids, har-

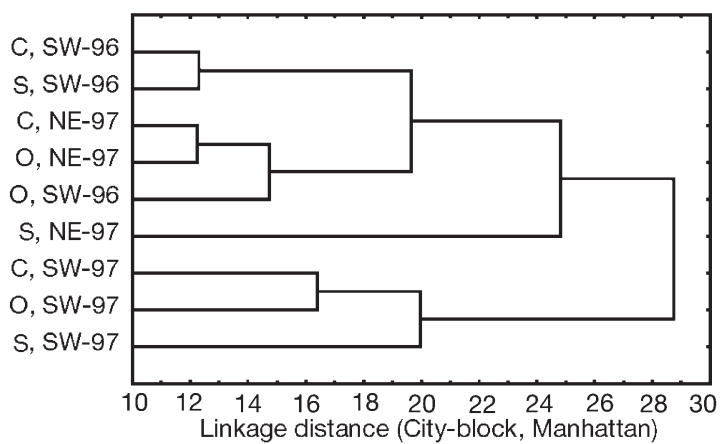

Fig. 6. Dendrogram from dissimilarity matrix (city-block [Manhattan] distance) of copepod abundance data (log $[x+1]$ transformed) with unweighted pair-group average linkage. ( $\mathrm{C}=$ coastal, $\mathrm{S}=$ shelf, $\mathrm{O}=$ offshore $)$

pacticoids and nauplii) for further analysis (Fig. 7, Table 5). Nauplii were the most abundant group on all cruises and transects $(47.3 \pm 1.8 \%$, mean $\pm \mathrm{SE}, \mathrm{n}=74)$ followed by calanoids and cyclopoids $(22.6 \pm 0.9$ and $25.5 \pm 1.0 \%$, respectively). Harpacticoids made up the smallest fraction $(4.6 \pm 0.4 \%)$.

Table 4. Abundance (ind. $\mathrm{m}^{-2}$; mean $\pm \mathrm{SE}$ ) of copepods at 3 different localities along the middle transect from 3 cruises on the Andaman Sea

\begin{tabular}{|c|c|c|c|}
\hline Taxa & Coastal (Stn 18) & Shelf (Stn 14) & Offshore (Stn 10) \\
\hline Acartia spp. & $308 \pm 142$ & $7322 \pm 458$ & $245 \pm 143$ \\
\hline Acrocalanus spp. & $952 \pm 487$ & $2486 \pm 1125$ & $755 \pm 285$ \\
\hline Calanopia elliptica & $109 \pm 33$ & $221 \pm 148$ & $60 \pm 4$ \\
\hline Calocalanus pavo & $66 \pm 66$ & $107 \pm 107$ & $164 \pm 42$ \\
\hline Calocalanus spp. & $185 \pm 95$ & $693 \pm 376$ & $76 \pm 47$ \\
\hline Candacia spp. & $233 \pm 150$ & $289 \pm 180$ & $230 \pm 81$ \\
\hline Canthocalanus pauper & $275 \pm 71$ & $414 \pm 36$ & $205 \pm 90$ \\
\hline Centropages sp. & 0 & $107 \pm 107$ & $9 \pm 9$ \\
\hline Centropges furcatus & $277 \pm 144$ & $245 \pm 125$ & $104 \pm 104$ \\
\hline Copilia spp. & $39 \pm 39$ & $182 \pm 151$ & $120 \pm 28$ \\
\hline Corycaeus spp. & $5356 \pm 3421$ & $8512 \pm 2445$ & $7085 \pm 3584$ \\
\hline Cyclopoid (juvenile) & 0 & $4971 \pm 4971$ & 0 \\
\hline Diaixis spp. & $5 \pm 5$ & $3581 \pm 3306$ & $53 \pm 40$ \\
\hline Eucalanus spp. & $392.4 \pm 131.6$ & $1582 \pm 1582$ & $499 \pm 100$ \\
\hline Euchaeta spp. & $433 \pm 104$ & $1762 \pm 295$ & $380 \pm 157$ \\
\hline Farranula gibbula & $267 \pm 16$ & $826 \pm 241$ & $1109 \pm 344$ \\
\hline Harpacticoid sp. (juvenile ) & $8225 \pm 8225$ & 0 & $1803 \pm 1803$ \\
\hline Harpacticoid sp. & $113 \pm 106$ & $14 \pm 14$ & $686 \pm 647$ \\
\hline Labidocera laevidentata & $5 \pm 5$ & 0 & 0 \\
\hline Macrosetella sp. & $413 \pm 200$ & $7224 \pm 7034$ & $1502 \pm 1295$ \\
\hline Metacalanus aurivilli & $207 \pm 103$ & $227 \pm 227$ & $56 \pm 30$ \\
\hline Microsetella sp. & $6028 \pm 4310$ & $34455 \pm 31208$ & $4400 \pm 2277$ \\
\hline Oithona spp. & $19908 \pm 11983$ & $23653 \pm 15029$ & $22787 \pm 16133$ \\
\hline Oncaea spp. & $7167 \pm 1448$ & $33081 \pm 21818$ & $21131 \pm 10741$ \\
\hline Other calanoid & $15580 \pm 7861$ & $92640 \pm 44574$ & $19323 \pm 7351$ \\
\hline Pontellina spp. & $10 \pm 10$ & $83 \pm 43$ & $66 \pm 36$ \\
\hline Pontellopsis yamadae & 0 & $7 \pm 7$ & 0 \\
\hline Sapphirina & $98 \pm 98$ & $13 \pm 12$ & $200 \pm 73$ \\
\hline Scolecthricella longispinosa & $42 \pm 21$ & $537 \pm 457$ & $171 \pm 57$ \\
\hline Temora spp. & $113 \pm 76$ & $331 \pm 174$ & $47 \pm 25$ \\
\hline
\end{tabular}



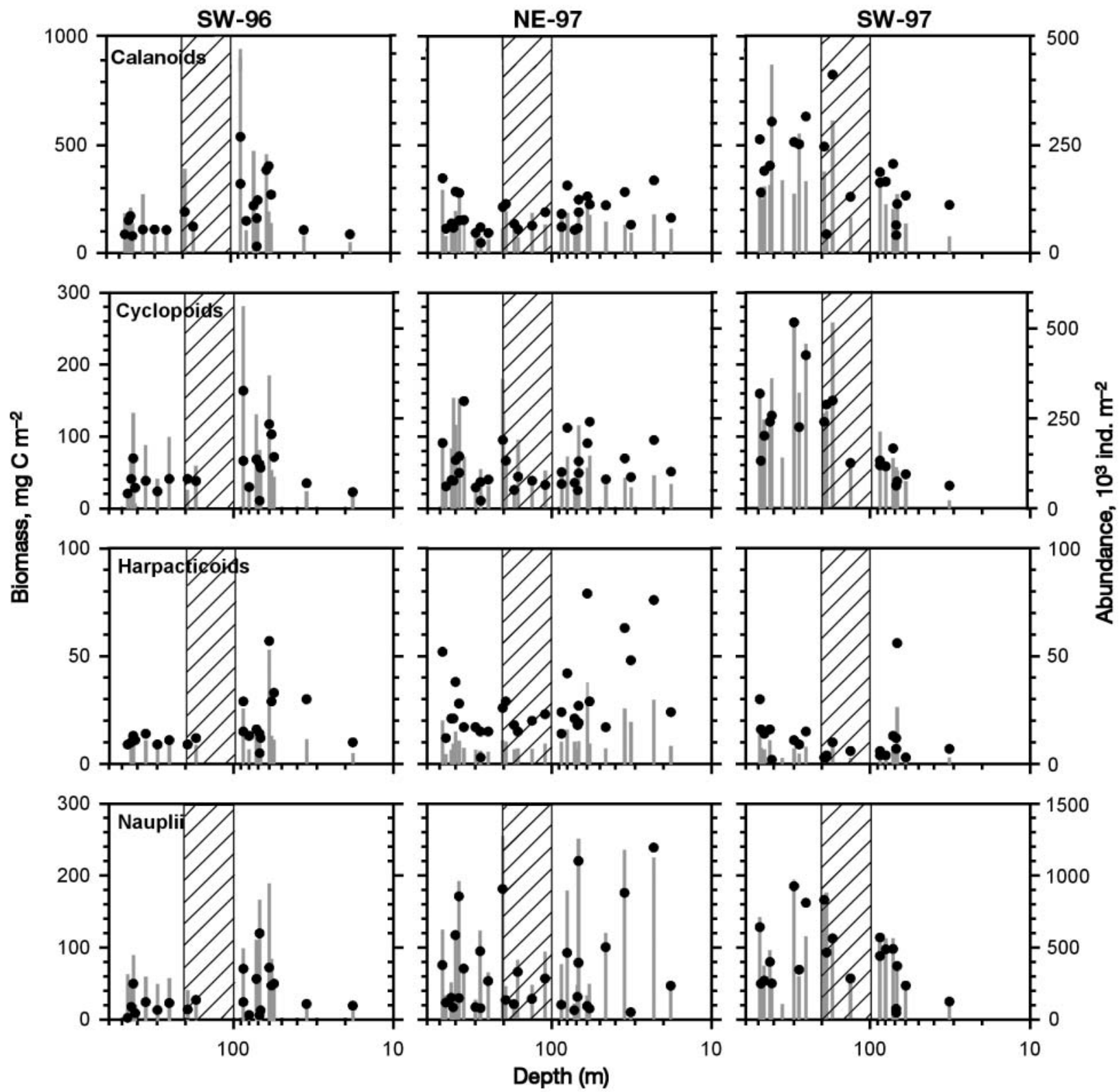

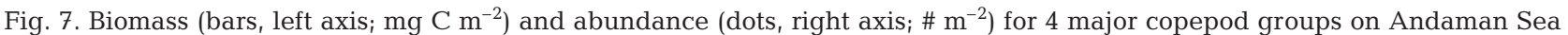
cruises during 1996 and 1997. Hatched area indicates the upper shelf break at 100 to $200 \mathrm{~m}$

Table 5. Abundance $\left(10^{3}\right.$ ind. $\mathrm{m}^{-2}$; mean $\left.\pm \mathrm{SE}\right)$ of major copepod groups from all cruises and transects in the Andaman Sea

\begin{tabular}{|c|c|c|c|c|c|c|c|c|c|c|c|}
\hline & \multicolumn{4}{|c|}{-SW-96 } & \multicolumn{4}{|c|}{ - NE-97 } & \multicolumn{2}{|r|}{ - SW-97 } & \multirow[b]{2}{*}{$\begin{array}{c}\text { All } \\
(\mathrm{n}=21)\end{array}$} \\
\hline & $\begin{array}{c}1 \\
(\mathrm{n}=9)\end{array}$ & $\begin{array}{c}2 \\
(\mathrm{n}=10)\end{array}$ & $\begin{array}{c}3 \\
(\mathrm{n}=2)\end{array}$ & $\begin{array}{c}\text { All } \\
(\mathrm{n}=21)\end{array}$ & $\begin{array}{c}1 \\
(\mathrm{n}=8)\end{array}$ & $\begin{array}{c}2 \\
(\mathrm{n}=13)\end{array}$ & $\begin{array}{c}3 \\
(\mathrm{n}=11)\end{array}$ & $\begin{array}{c}\text { All } \\
(\mathrm{n}=32)\end{array}$ & $\begin{array}{c}1 \\
(\mathrm{n}=12)\end{array}$ & $\begin{array}{c}2 \\
(\mathrm{n}=9)\end{array}$ & \\
\hline Nauplii & $213 \pm 60$ & $114 \pm 33$ & $178 \pm 71$ & $162 \pm 32$ & $105 \pm 14$ & $214 \pm 39$ & $658 \pm 105$ & $339 \pm 57$ & $421 \pm 82$ & $424 \pm 63$ & $422 \pm 53$ \\
\hline Calanoids & $80 \pm 16$ & $110 \pm 25$ & $94 \pm 41$ & $96 \pm 14$ & $69 \pm 9$ & $91 \pm 11$ & $106 \pm 13$ & $91 \pm 7$ & $182 \pm 33$ & $196 \pm 20$ & $188 \pm 21$ \\
\hline Cyclopoids & $104 \pm 21$ & $114 \pm 28$ & $106 \pm 36$ & $109 \pm 16$ & $82 \pm 15$ & $128 \pm 23$ & $123 \pm 13$ & $115 \pm 11$ & $223 \pm 44$ & $167 \pm 22$ & $199 \pm 27$ \\
\hline Harpacticoids & $16 \pm 5$ & $15 \pm 2$ & $31 \pm 1$ & $17 \pm 3$ & $30 \pm 8$ & $24 \pm 3$ & $31 \pm 6$ & $28 \pm 3$ & $11 \pm 2$ & $13 \pm 6$ & $12 \pm 3$ \\
\hline Total & $414 \pm 92$ & $353 \pm 86$ & $410 \pm 150$ & $385 \pm 56$ & $286 \pm 32$ & $458 \pm 65$ & $917 \pm 130$ & $573 \pm 69$ & $837 \pm 152$ & $2799 \pm 74$ & $820 \pm 91$ \\
\hline
\end{tabular}


Biomass

Copepod biomass ranged from 80 to $1300 \mathrm{mg} \mathrm{C} \mathrm{m}^{-2}$, with an average of $381 \pm 28 \mathrm{mg} \mathrm{C} \mathrm{m}^{-2}$. The average biomasses from Cruises SW-96, NE-97 and SW-97 were $366 \pm 65,310 \pm 25$, and $493 \pm 56 \mathrm{mg} \mathrm{C} \mathrm{m}^{-2}$, respectively. No distinct peaks or patterns could be observed in any specific areas on the transects (Fig. 3).

The calanoids made up to half of the total copepod biomass, $54.1 \pm 1.6 \%$ (mean $\pm \mathrm{SE}, \mathrm{n}=75$ ), while the cyclopoid and poecilostomatoids contributed less, $21.4 \pm 1.1 \%$. The nauplii (of all copepod species) contributed $21.6 \pm 1.4 \%$ of the total biomass, and harpacticoid copepods accounted for only $2.9 \pm 0.3 \%$. The diversity of the calanoid copepods was very high, with more than 100 species. The Cyclopoids primarily belonged to Oithona, poecilostomatoids were dominated by Oncaea and Corycaeus, and the harpacticoids belonged to 2 genera, Microsetella and Macrosetella.

\section{EP and SEP}

Despite the very high diversity of copepods it was possible to find 7 species that were present at all stations visited (Table 6). Four were broadcast spawners (Acartia australis, Acrocalanus gibber, Centropages furcatus and Temora discaudata) and 3 were eggcarriers (the cyclopoid Oithona plumifera, the poecilostomatoid Oncaea venusta, and the calanoid Euchaeta marinella).

\section{Free-spawning species}

The egg production of the selected species varied along transects and between cruises (Fig. 8, Table 6). Temora discaudata had the highest EP rate (35.9 \pm 2.0 egg $\mathrm{fem}^{-1} \mathrm{~d}^{-1}$ ), followed by Acrocalanus gibber $\left(8.8 \pm 0.6\right.$ egg fem $\left.{ }^{-1} \mathrm{~d}^{-1}\right)$, Centropages furcatus $(7.7 \pm$ 0.8 egg fem $\mathrm{f}^{-1}$ ), and Acartia australis (1.8 \pm 0.2 egg fem ${ }^{-1} \mathrm{~d}^{-1}$, Table 6). A. gibber had the highest $\operatorname{SEP}(0.14 \pm 0.02, \mathrm{n}=61)$, followed by $T$. discaudata $(0.08 \pm 0.02, \mathrm{n}=58), C$. furcatus $(0.03 \pm 0.01, \mathrm{n}=61)$ and $A$. australis $(0.01 \pm 0.002, \mathrm{n}=60)$ (Fig. 9. In general, no patterns in egg production were observed along a transect $(p>0.1)$. However, A. australis was an exception during Cruise NE-97 (coastal $>$ shelf $>$ offshore, $p<0.01$ ). Since the egg production experiments were conducted along the transects, the incubations were started at different times of the day, i.e. from 09:00 to 18:00 h. The potential influence of diel cycles on EP rates was tested by comparing EP in relation to the mid-time of the experiment. The experiments were divided into the following 3 time groups: $12: 00$ to $14: 00,15: 00$ to 18:00 and 18:00 to 21:00 h. In general, no significant difference was observed in the EP rate in relation to time of the day, except for Acrocalanus, where production was significantly higher around dusk 18:00 to $21: 00$ ( $p<0.001)$. Another potential source of variability in egg production could be egg cannibalism; However, the number of females in the incubation bottles (1 to 6 ) and the measured egg production rate were uncorrelated, indicating that egg predation was insignificant.

\section{Egg carrying species}

Hatching rate was determined routinely for Oncaea venusta at all stations. For Oithona plumifera and the Euchaeta marinella, most females lost their egg sacs in the net, and only a few experiments were conducted (Table 7). Because of the limited numbers of hatching experiments for $O$. plumifera and E. marinella, their mean values were used in the SEP calculations for all stations. The daily egg production rate of the eggcarrying species ranged from $2.4 \pm 0.2$ for Oithona to $3.2 \pm 0.3$ for Euchaeta, to $11.5 \pm 0.9$ for Oncaea

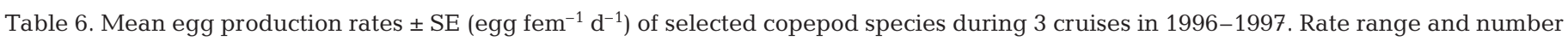
of experiments (n) are given in parentheses

\begin{tabular}{|c|c|c|c|c|c|c|c|c|c|c|c|c|}
\hline & \multicolumn{3}{|c|}{ SW-96 } & \multicolumn{3}{|c|}{ NE-97 } & \multicolumn{3}{|c|}{ SW-97 } & \multicolumn{3}{|c|}{ All cruises } \\
\hline & Mean $\pm \mathrm{SE}$ & Range & $\mathrm{n}$ & Mean \pm SE & Range & $\mathrm{n}$ & Mean \pm SE & Range & $\mathrm{n}$ & Mean $\pm \mathrm{SE}$ & Range & $\mathrm{n}$ \\
\hline Acartia australis & $2.1 \pm 0.3$ & $0-10.7$ & 85 & $1.8 \pm 0.3$ & $0-19.3$ & 145 & $1.3 \pm 0.7$ & $0-36.9$ & 63 & $1.8 \pm 0.2$ & $0-36.9$ & 293 \\
\hline Acrocalanus gibber & $8.9 \pm 1.0$ & $0-28.3$ & 66 & $10.9 \pm 1.0$ & $0-61.9$ & 142 & $5.4 \pm 0.9$ & $0-50.8$ & 93 & $8.8 \pm 0.6$ & $0-61.9$ & 301 \\
\hline Centropages furcatus & s $10.4 \pm 2.3$ & $0-54.7$ & 46 & $8.3 \pm 1.1$ & $0-80.3$ & 131 & $5.4 \pm 1.2$ & $0-47.8$ & 85 & $7.7 \pm 0.8$ & $0-80.3$ & 262 \\
\hline Euchaeta marinella & $4.2 \pm 1.0$ & $0.9-11.1$ & 10 & $2.3 \pm 0.3$ & $0.5-4.9$ & 22 & $3.7 \pm 0.6$ & $0.1-10.5$ & 22 & $3.2 \pm 0.3$ & $0.1-11.1$ & 54 \\
\hline Oncaea venusta & $9.0 \pm 1.0$ & $4.0-17.7$ & 18 & $15.8 \pm 1.5$ & $4.5-38.1$ & 32 & $7.1 \pm 0.9$ & $0.6-14.3$ & 22 & $11.5 \pm 0.9$ & $0.6-38.1$ & 72 \\
\hline Oithona plumifera & $3.1 \pm 0.4$ & $0.9-9.0$ & 21 & $2.7 \pm 0.4$ & $0.3-11.2$ & 32 & $1.4 \pm 0.2$ & $0.2-3.6$ & 22 & $2.4 \pm 0.2$ & $0.2-11.2$ & 76 \\
\hline Temora discaudata & $32.6 \pm 4.1$ & $0-137.3$ & 62 & $42.5 \pm 2.8$ & 0-195.3 & 139 & $23.2 \pm 3.1$ & $0-174.4$ & 78 & $34.9 \pm 2.0$ & 0-195.3 & 279 \\
\hline
\end{tabular}


SW-96
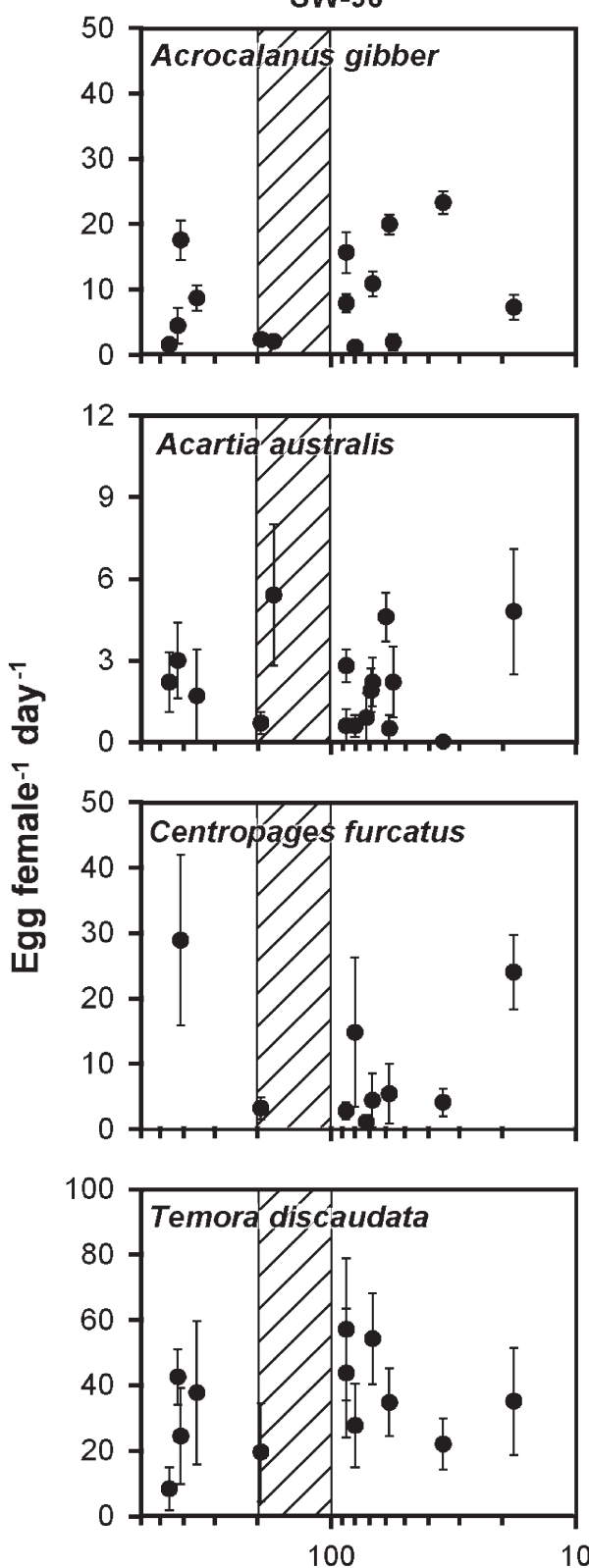
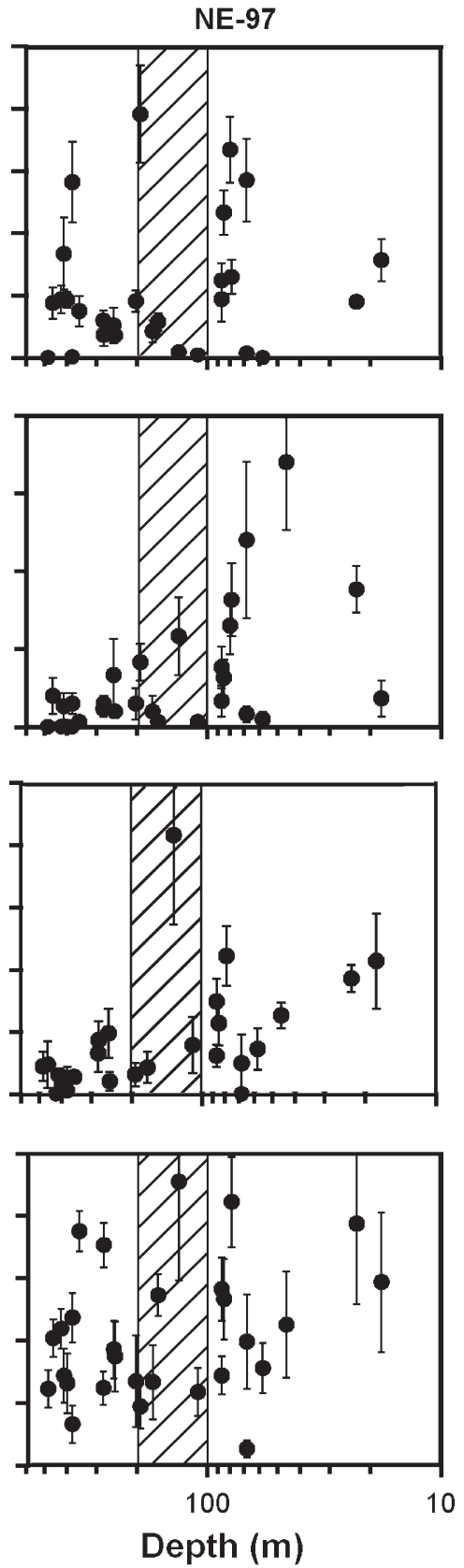

SW-97
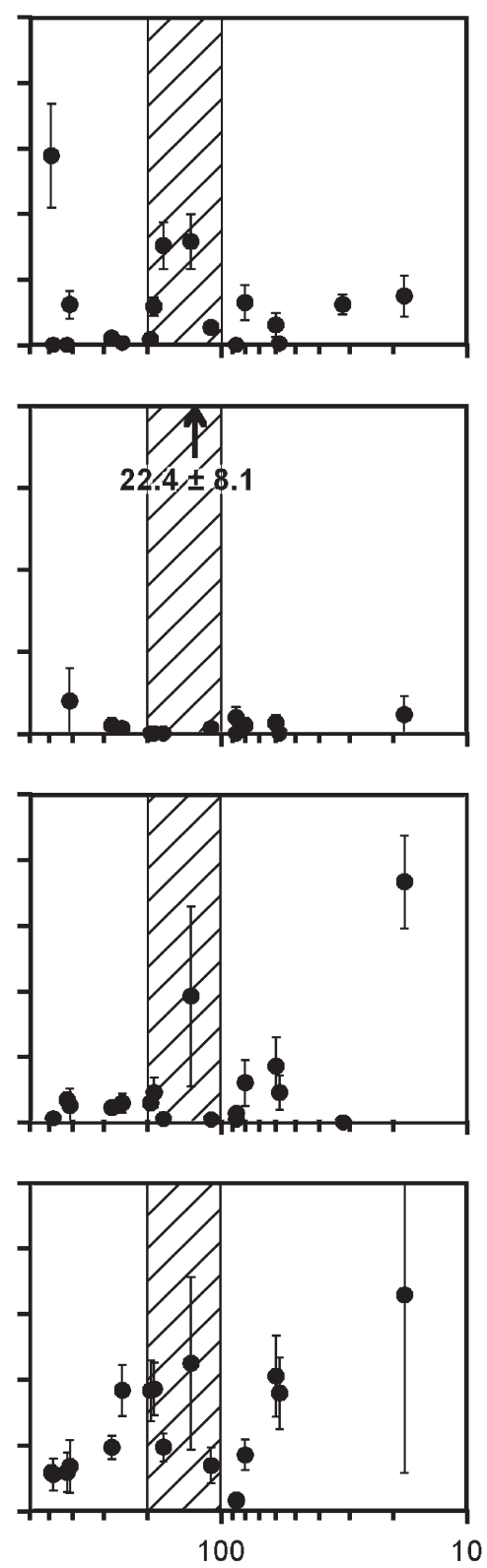

Fig. 8. Egg production rates of 4 broadcasting calanoid copepods (egg fem ${ }^{-1} \mathrm{~d}^{-1}$ ) on Andaman Sea cruises in 1996 and 1997. Hatched area indicates the upper shelf break at 100 to $200 \mathrm{~m}$

Table 7. Hatching rates (HR) of the 3 egg carrying species at $25^{\circ} \mathrm{C} . \mathrm{n}$ : number of experiments

\begin{tabular}{|lcrr|}
\hline & \multicolumn{3}{c|}{ HR $\left(\% \mathrm{~d}^{-1}\right)$} \\
& Mean \pm SE & Range & \multicolumn{1}{c|}{$\mathrm{n}$} \\
\hline Euchaeta marinella & $49.1 \pm 2.6$ & $34.7-57.7$ & 8 \\
Oncaea venusta & $23.4 \pm 0.8$ & $17.5-39.9$ & 45 \\
Oithona plumifera & $49.2 \pm 1.7$ & $46.4-54.2$ & 4 \\
\hline
\end{tabular}

(Table 6, Fig. 10). Euchaeta had the highest SEP $(0.15 \pm 0.02, \mathrm{n}=54)$, followed by Oithona $(0.05 \pm 0.01$, $\mathrm{n}=75)$, and Oncaea $(0.02 \pm 0.002, \mathrm{n}=72)$ (Fig. 11). In general, there was no difference in EP for the 3 egg carrying species among localities ( $p>0.05$, Fig. 9, Table 6), except for $O$. venusta during Cruise NE-97. On this cruise, $O$. venusta at the coastal stations had a higher EP than the females from the shelf and offshore areas $(p<0.05)$. 
Productivity

Copepod productivity ranged from 2 to $70 \mathrm{mg} \mathrm{C}$ $\mathrm{m}^{-2} \mathrm{~d}^{-1}$ (Fig. 12, Table 8). Highest production was found at the shelf break front region on Cruises SW96 and NE-97, while Cruise SW-97 had highest productivity towards the outermost stations. There were, however, no significant differences between localities ( $p>0.1$ ) for any cruise. Locality differences could only be seen when data from all cruises were pooled, showing higher production for harpacticoids at the coastal stations, compared to shelf and offshore areas $(\mathrm{p}<0.05)$.

\section{Inter-annual variation}

Data on copepod abundance, biomass and production between the 2 cruises during the SW-monsoon period (Cruises SW-96 and SW-97) were compared using the $F$ test in 1-way ANOVA. Data from all transects of each cruise were pooled in order to achieve a larger data set.

Abundance and biomass

The 2 cruises showed inter-annual differences for abundance in all major groups of copepods. Total
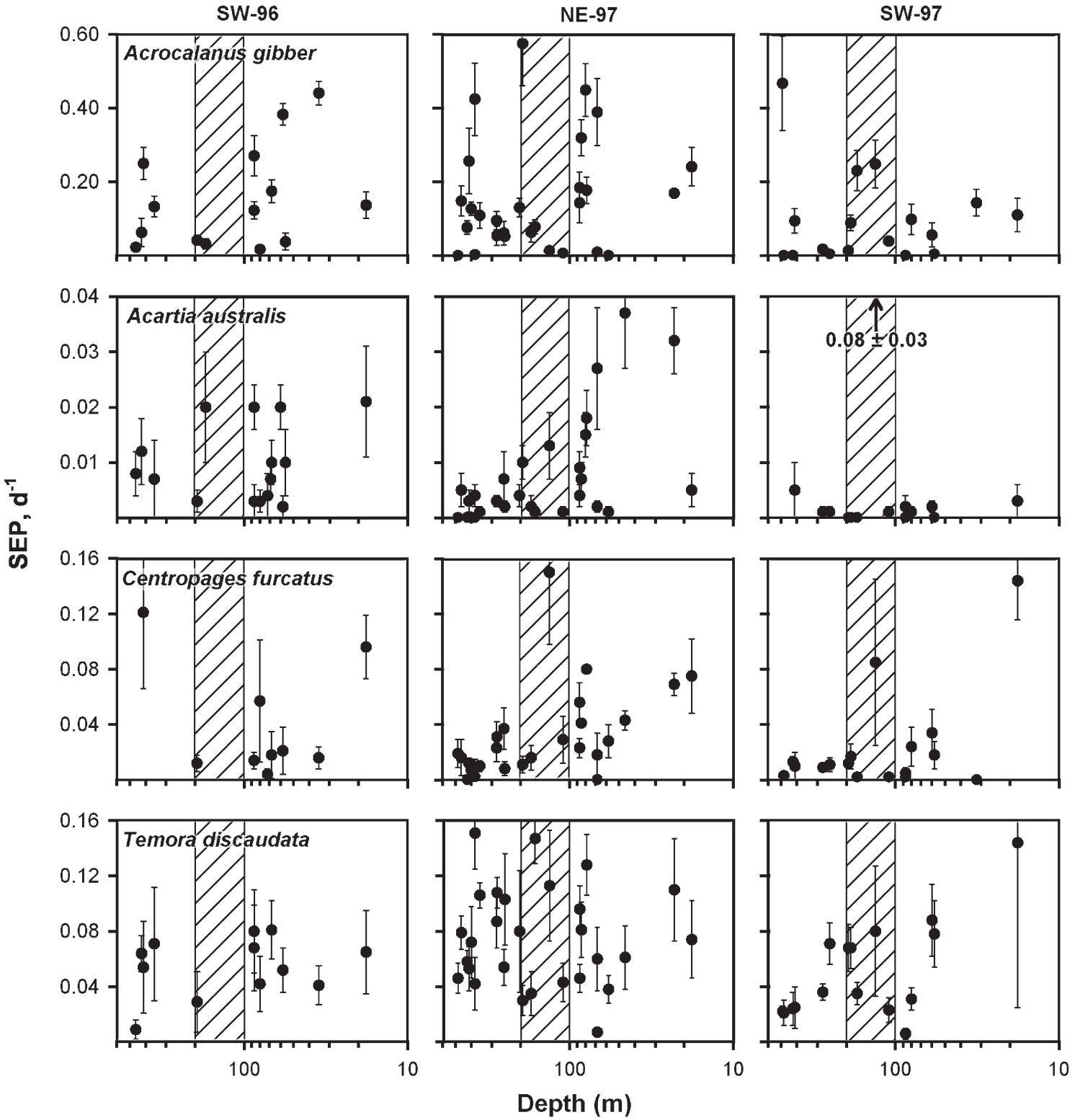

Fig. 9. Carbon-specific egg production rate $\left(\mathrm{SEP}, \mathrm{d}^{-1}\right)$ of the 4 broadcasting calanoid copepods on Andaman Sea cruises during 1996 and 1997. Hatched area indicates the upper shelf break at 100 to $200 \mathrm{~m}$ 

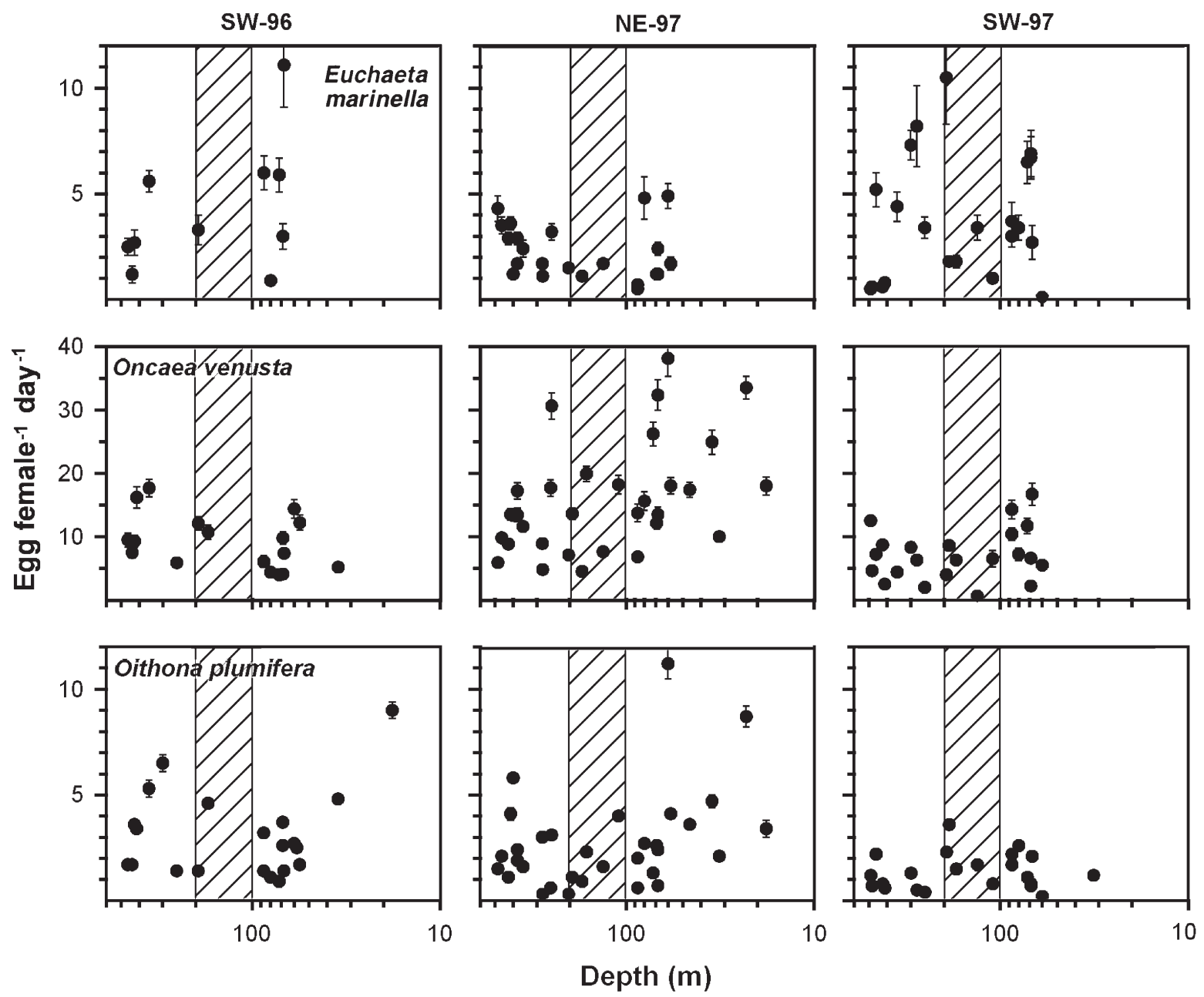

Fig. 10. Egg production rates of 3 egg carrying copepods (egg fem ${ }^{-1} \mathrm{~d}^{-1}$ ) on Andaman Sea cruises in 1996 and 1997. Hatched area indicates the upper shelf break at 100 to $200 \mathrm{~m}$

copepods abundance was significantly higher on Cruise SW-97 ( $\mathrm{p}<0.001)$. At the major group level, only harpacticoids had a higher abundance in 1996 $(\mathrm{p}<0.05)$, while the other groups had a higher abundance in 1997 (nauplii, $\mathrm{p}<0.001$; cyclopoids, $\mathrm{p}<0.01$; calanoids, $\mathrm{p}<0.001$ ). Total copepod biomass displayed no inter-annual differences ( $p>0.7$ ), but the cyclopoids had significantly higher biomass in 1997 compared to $1996(\mathrm{p}<0.05)$.

\section{Egg production and productivity}

Generally, no EP differences were found for copepod species between the SW monsoon cruises of 1996 and 1997 (Table 6). The exceptions were higher EP for Acartia australis $(\mathrm{p}<0.05)$ and Oithona plumifera $(\mathrm{p}<$ 0.001) in 1996 and higher SEP for Centropages furca- tus $(\mathrm{p}<0.05)$ and O. plumifera $(\mathrm{p}<0.001)$ in 1996. There were no differences between years for total copepod production or production of individual groups, except higher production of harpacticoids $(p<0.001)$ in 1996 compared to 1997.

\section{Seasonal variation}

Data from Cruise SW-96 were selected to represent the SW monsoon, based on the same type of sampling gear employed during Cruises SW-96 and NE-97. Only minor differences were observed between the 2 seasons. The only significant differences were: (1) higher abundances of nauplii ( $\mathrm{p}<0.05)$; harpacticoids $(\mathrm{p}<$ $0.0001)$ and total copepods $(p<0.05)$ during the NE monsoon and (2) higher EP and SEP for Oncaea venusta during the NE monsoon $(\mathrm{p}<0.001)$. 


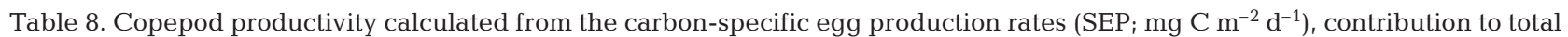
production (percentage of total) and productivity:biomass (P:B) ratio averaged for 3 cruises in the Andaman Sea

\begin{tabular}{|llccccc}
\hline & & SW-96 & NE-97 & SW-97 & All cruises \\
\hline Calanoid & Productivity & $17.3 \pm 3.6$ & $10.5 \pm 1.2$ & $19.4 \pm 3.2$ & $15.1 \pm 1.5$ \\
& Percentage of total & $70.4 \pm 14.6$ & $52.0 \pm 5.9$ & $72.0 \pm 12.0$ & $64.3 \pm 6.5$ \\
& P:B & $0.08 \pm 0.01$ & $0.08 \pm 0.01$ & $0.08 \pm 0.01$ & $0.08 \pm 0.004$ \\
Cyclopoid & Productivity & $2.7 \pm 0.5$ & $2.7 \pm 0.4$ & $2.0 \pm 0.3$ & $2.5 \pm 0.2$ \\
& Percentage of total & $10.8 \pm 2.0$ & $13.4 \pm 1.9$ & $7.4 \pm 1.1$ & $10.6 \pm 1.0$ \\
& P:B & $0.05 \pm 0.01$ & $0.04 \pm 0.004$ & $0.02 \pm 0.01$ & $0.03 \pm 0.003$ \\
Harpacticoid & Productivity & $0.6 \pm 0.1$ & $0.9 \pm 0.3$ & $0.2 \pm 0.05$ & $0.6 \pm 0.1$ \\
& Percentage of total & $2.6 \pm 0.6$ & $4.3 \pm 1.4$ & $0.6 \pm 0.2$ & $2.5 \pm 0.5$ \\
& P:B & $0.06 \pm 0.01$ & $0.05 \pm 0.01$ & $0.03 \pm 0.004$ & $0.05 \pm 0.01$ \\
& Productivity & $4.0 \pm 0.7$ & $6.1 \pm 1.1$ & $5.4 \pm 1.3$ & $5.3 \pm 0.7$ \\
Total & Percentage of total & $16.2 \pm 3.0$ & $30.3 \pm 5.7$ & $20.0 \pm 5.0$ & $22.6 \pm 2.8$ \\
& P:B & $0.07 \pm 0.01$ & $0.07 \pm 0.004$ & $0.06 \pm 0.01$ & $0.06 \pm 0.003$ \\
& Productivity & $24.6 \pm 4.4$ & $20.1 \pm 2.3$ & $26.9 \pm 4.5$ & 100 & $23.4 \pm 2.1$ \\
& Percentage of total & 100 & 100 & $0.06 \pm 0.01$ & $0.064 \pm 0.003$ \\
\hline
\end{tabular}
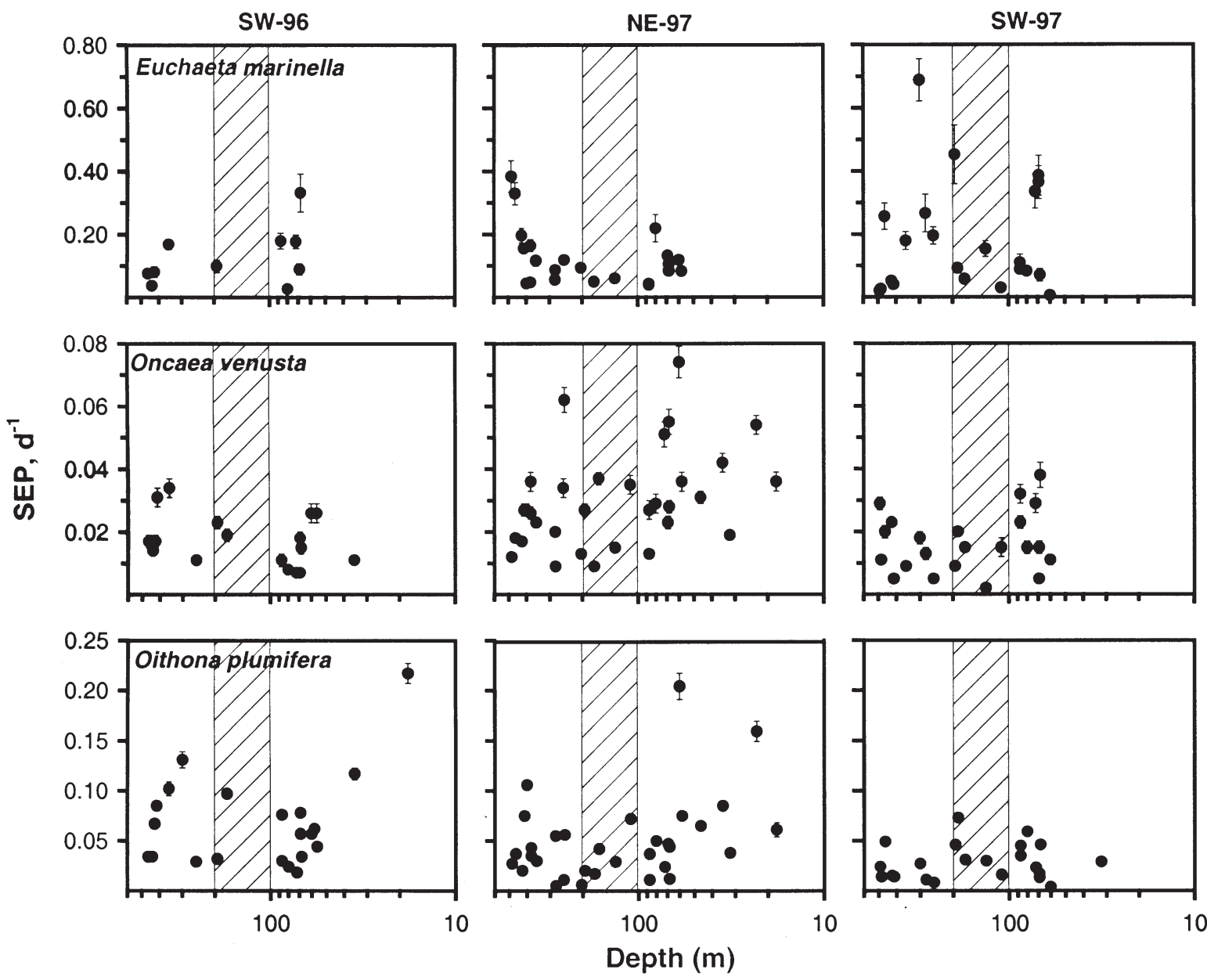

Fig. 11. Carbon-specific egg production rate (SEP, $\mathrm{d}^{-1}$ ) of the 3 egg carrying copepods on Andaman Sea cruises during 1996 and 1997. Hatched area indicates the upper shelf break at 100 to $200 \mathrm{~m}$ 

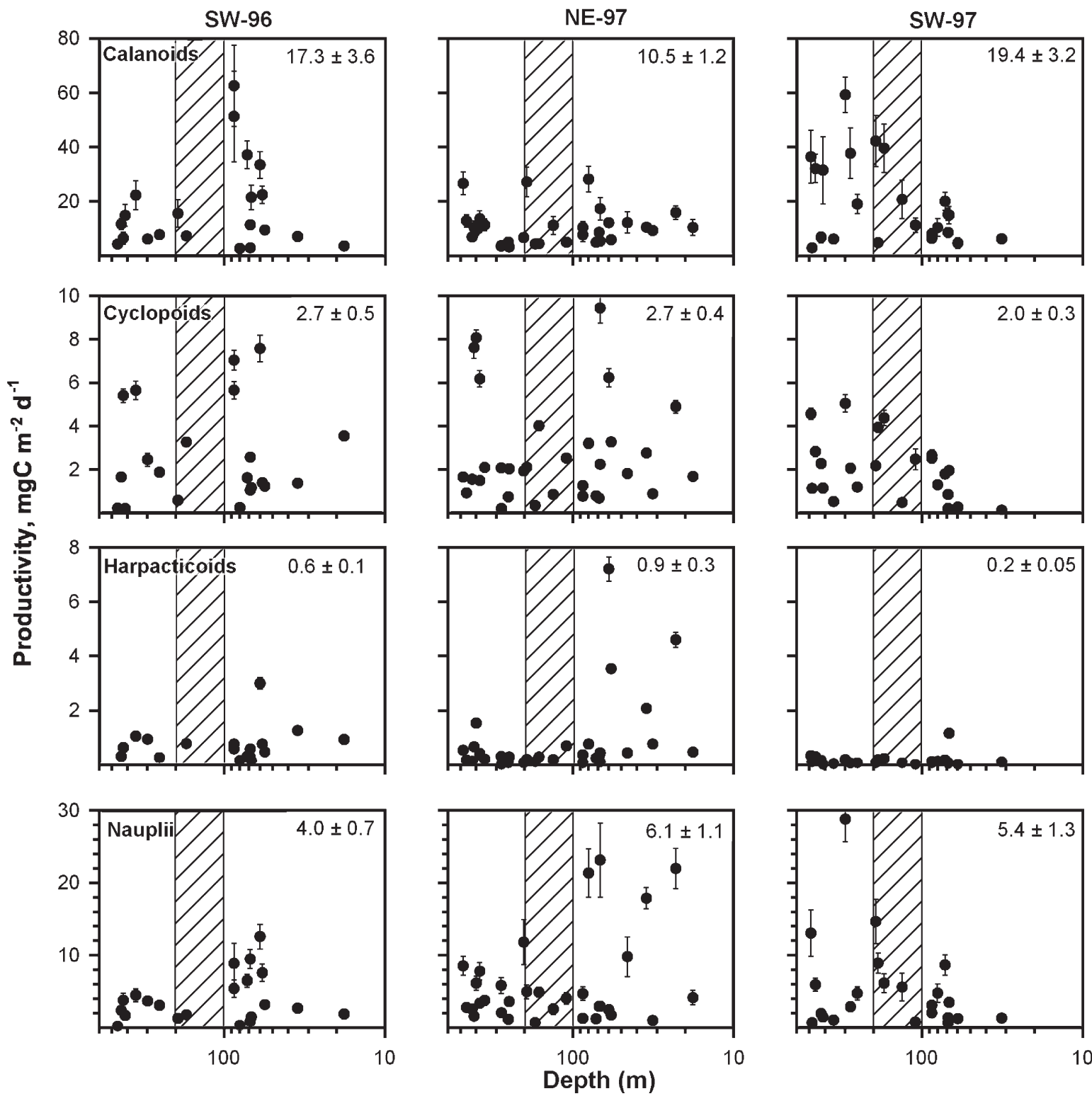

Fig. 12. Copepod productivity $\left(\mathrm{mg} \mathrm{C} \mathrm{m}^{-2} \mathrm{~d}^{-1}\right.$ ) on Andaman Sea cruises during 1996 and 1997 . Hatched area indicates the upper shelf break at 100 to 200

\section{Correlation between SEP and food availability}

Correlations of SEP among different copepod species were low (Table 9). Oithona plumifera and Oncaea venusta were the most correlated $(\mathrm{p}<0.001, \mathrm{n}=71)$, followed by Centropages furcatus and Acartia australis $(\mathrm{p}<0.01, \mathrm{n}=57)$, and C. furcatus and O. plumifera $(\mathrm{p}<$ $0.05, \mathrm{n}=57)$. Specific egg production of $A$. australis was also significantly correlated to SEP of Acrocalanus gibber $(\mathrm{p}<0.05, \mathrm{n}=57)$.

Correlations between SEPs of these 7 copepod species and food availability were calculated at 2 depths, $5 \mathrm{~m}$ and FM (Table 10). SEPs of the free-spawners were significantly correlated to phytoplankton and ciliate biomass but not to the abundance of heterotrophic dinoflagellates. For Euchaeta marinella, SEP had the poorest correlations to all food types at both depths, and many of them were even negative, illustrating its well-known predatory feeding biology. SEP of Oithona plumifera was significantly correlated to most of the food types $(\mathrm{p}<0.001$, see Table 10$)$. SEP of Oncaea venusta correlated well with phytoplankton and biomass of all prey items combined ( $p<0.01$ ), but not to heterotrophic dinoflagellates alone. Copepod production was not significantly correlated to any of the potential prey items. 
Table 9. Correlations among carbon-specific egg production rates (SEPs) of different copepod species. Significant correlations are shown in bold. ${ }^{*} \mathrm{p}<0.05{ }^{* * *} \mathrm{p}<0.001$

\begin{tabular}{|lccccc|}
\hline & $\begin{array}{c}\text { Acartia } \\
\text { australis }\end{array}$ & $\begin{array}{c}\text { Acrocalanus } \\
\text { gibber }\end{array}$ & $\begin{array}{c}\text { Centropages } \\
\text { furcatus }\end{array}$ & $\begin{array}{c}\text { Temora } \\
\text { discaudata }\end{array}$ & $\begin{array}{c}\text { Euchaeta } \\
\text { marinella }\end{array}$ \\
$\begin{array}{l}\text { Oncaea } \\
\text { venusta }\end{array}$ \\
\hline Acrocalanus gibber & $\mathbf{0 . 2 7}^{*}$ & & & & \\
Centropages furcatus & $\mathbf{0 . 3 3}^{*}$ & -0.01 & & & \\
Temora discaudata & 0.13 & 0.00 & 0.01 & 0.11 & -0.13 \\
Euchaeta marinella & 0.03 & 0.05 & -0.05 & 0.21 & -0.07 \\
Oncaea venusta & 0.03 & 0.17 & 0.01 & -0.02 & $\mathbf{0 . 5 2}$ \\
Oithona plumifera & 0.17 & 0.13 & $\mathbf{0 . 3 3}^{*}$ & & \\
\hline
\end{tabular}

\section{DISCUSSION}

\section{Spatial and temporal patterns in biomass and productivity: any pattern or trend?}

The Andaman Sea is recognized as the site of the world's largest solitons (Osborne \& Burch 1980). When the soliton packets encounter the shelf, nutrient rich water should intrude into the surface layer. Such hydrographic discontinuities or episodic disturbances of the water column are often sites of enhanced plankton production (Legendre 1981). The shelf-break front of the Andaman Sea has the potential of being a zooplankton hotspot (sensu Marine Zooplankton Colloquium 2001). Previous investigations in the Andaman Sea (Wium-Andersen 1977, Kiørboe et al. 1991) suggested that this front was highly productive and potentially important for the productivity of the area. However, we found no peak in primary production (Nielsen et al. 2004), copepod biomass (Figs. 3 \& 7) or egg production (Figs. $8 \& 10$ ) in association with the shelfbreak front. One possible explanation for our observations is that strong stratification of the water column prevented substantial breakage of the internal wave, and that only small pulses of nitrate are transported to the upper mixed layer at regular intervals. The only site of particular high production was at the persistent mid-shelf front where breaking of the shoaling waves introduced cold, salty and nutrient-rich water to the euphotic zone (Nielsen et al. 2004).

The seasonal patterns of tropical pelagic communities are fundamentally different from those at higher latitudes, since only weak seasonal variations in plankton communities are evident (Chisholm \& Roff 1990b, Webber \& Roff 1995a,b, Madhupratap et al. 1996, Roman et al. 2000). The relatively weak seasonal fluctuations in plankton biomass or productivity found in the tropics can be related to the rather variable pattern of rainfall (Chisholm \& Roff 1990b) and increased storm frequency during monsoon periods and associated upwelling events (Smith 1982, Schalk 1987 , Baars et al. 1990).
The Andaman Sea west of Thailand experiences 2 main seasons: the relatively calm dry NE monsoon (November to March) and the stormy wet SW (May to September) monsoon period. The NE monsoon is characterized by northeasterly dry winds off the Asian continent. Heavy rain and strong winds characterize the SW monsoon. Previous investigations in Thai coastal waters, which are more influenced by surface run-off from land, have shown that zooplankton usually peak in abundance during the NE monsoon (Suwanrumpha 1980a,b, Boonruang 1985, Poung-In 1992, Satapoomin 1999b, Satapoomin \& Pornchai 2002).

During the present investigation, a significant deepening of the upper mixed layer through erosion of the pycnocline was observed during the 2 cruises in the SW monsoon compared to the NE monsoon (Fig. 2). However, this vertical mixing and introduction of nutrient rich waters to the upper part of the water column (Nielsen et al. 2004) was not reflected in the standing stock or production of the copepods during the SW monsoon. Also, despite the coverage from shallow coastal water across the shelf to oceanic deep stations, no spatial or seasonal variation in the species composition of the Andaman Sea copepod community was observed, i.e. no distinct coastal or deep-water communities were apparent (Table 4, Fig. 7). Moreover comparison between the 2 major seasons revealed no differences in the overall species composition of the copepod community either.

Such absence of detectable seasonality in the composition and biomass of zooplankton has been reported from other offshore tropical areas. In the Arabian Sea, although tropical and intensely seasonal (Burkill et al. 1993, Edwards et al. 1999, Roman et al. 2000), mesozooplankton standing stocks and abundance did not vary significantly between seasons and areas (Madhupratap et al. 1996), despite a clear seasonal pattern in phytoplankton biomass and primary production (Bhattathiri et al. 1996, Sawant \& Madhupratap 1996). Madhupratap et al. (1996) suggested that herbivorous mesozooplankton in the Arabian Sea are able to survive during periods of low phytoplank- 
Table 10. Correlations between copepod SEP and food availability at the sampling stations. Significant correlations are shown in bold. ${ }^{* *} \mathrm{p}<0.01{ }^{* * *} \mathrm{p}<0.001$

\begin{tabular}{|c|c|c|c|c|c|c|c|}
\hline & $\begin{array}{l}\text { Acartia } \\
\text { australis }\end{array}$ & $\begin{array}{l}\text { Acrocalanus } \\
\text { gibber }\end{array}$ & $\begin{array}{l}\text { Centropages } \\
\text { furcatus }\end{array}$ & $\begin{array}{l}\text { Euchaeta } \\
\text { marinella }\end{array}$ & $\begin{array}{l}\text { Oncaea } \\
\text { venusta }\end{array}$ & $\begin{array}{l}\text { Oithona } \\
\text { plumifera }\end{array}$ & $\begin{array}{c}\text { Temora } \\
\text { discaudata }\end{array}$ \\
\hline Phyto, $5 \mathrm{~m}$ & 0.15 & 0.08 & $0.39^{* *}$ & -0.13 & $0.33^{* *}$ & $0.37^{* * *}$ & 0.24 \\
\hline Ciliates, 5 m & 0.14 & 0.22 & 0.10 & -0.21 & $0.24^{* *}$ & $0.38^{* * *}$ & 0.07 \\
\hline Het Dino, $5 \mathrm{~m}$ & 0.15 & 0.08 & 0.18 & -0.14 & -0.05 & $0.48^{* * *}$ & 0.10 \\
\hline Cili +Dino, $5 \mathrm{~m}$ & 0.17 & 0.14 & 0.17 & -0.21 & 0.10 & $0.50^{* * *}$ & 0.10 \\
\hline Cili + Dino + Phyto, $5 \mathrm{~m}$ & 0.15 & 0.09 & $0.38^{* *}$ & -0.14 & $0.33^{* *}$ & $0.39^{* * *}$ & 0.23 \\
\hline $\mathrm{PP}, 5 \mathrm{~m}$ & -0.02 & 0.02 & $0.48^{* * *}$ & -0.07 & 0.11 & 0.10 & $0.49^{* * *}$ \\
\hline Phyto, FM & 0.23 & $0.43^{* * *}$ & 0.13 & -0.16 & $0.32^{* *}$ & $0.30^{* *}$ & 0.13 \\
\hline Ciliates, FM & $0.44^{* * *}$ & 0.22 & 0.05 & 0.10 & 0.03 & 0.10 & 0.06 \\
\hline Het Dino, FM & 0.18 & 0.14 & 0.24 & -0.11 & 0.21 & $0.50^{* * *}$ & 0.13 \\
\hline Cili + Dino, FM & $0.35^{* *}$ & 0.20 & 0.20 & 0.03 & 0.14 & $0.40^{* * *}$ & 0.12 \\
\hline Cili + Dino + Phyto, FM & 0.24 & $0.43^{* * *}$ & 0.23 & -0.15 & $0.32^{* *}$ & $0.32^{* *}$ & 0.16 \\
\hline $\mathrm{PP}, \mathrm{FM}$ & 0.16 & $0.49^{* * *}$ & 0.23 & 0.05 & 0.10 & 0.05 & 0.11 \\
\hline
\end{tabular}

ton standing stock by feeding on organisms in the microbial loop, thereby keeping a constant biomass despite the seasonal variation in the primary producers. This is consistent with the fact that maximum biomass of microzooplankton occurred during an intermonsoon season, when primary production and chl a were low (Guans et al. 1996). In Jamaica, Hopcroft et al. (1998a) found no relationship between copepod biomass and chl $a$, and suggested that phytoplankton is generally not the factor modulating copepod community. Instead, they speculated that the copepod community might be predator regulated (Hopcroft et al. 1998a). Although significant fluctuations in most of the physical and chemical parameters occurred, detailed analysis of the annual structure of the copepod community off Discovery Bay, Jamaica, revealed no seasonality in overall copepod species composition or diversity (Webber \& Roff 1995a).

The limited spatial and seasonal variation in planktonic communities in oligotrophic tropical ecosystems complicates determination of relationships between phytoplankton and zooplankton communities. In temperate and arctic ecosystems, where the range in biomass is wider, such relationships exist and phytoplankton and zooplankton do co-vary (Levinsen \& Nielsen 2002). Analysis of longer time series may, however, reveal significant seasonal variation in zooplankton biomass. Although the pelagic food web in the central North Pacific Ocean has long been characterized by its general monotony, Landry et al. (2001) found significant seasonal differences, with highest biomass observed during the summer, using the analysis of a long time series of mesozooplankton off Hawaii. Surprisingly, the peak of mesozooplankton biomass did not match the winter peak in phytoplankton generated by the winter storms; the summer peak was rather a response to the summer blooms of the nitrogen-fixing cyanobacteria, Trichodesmium.
Due to the lack of any seasonal or spatial variation in copepod biomass, production and species composition in the Andaman Sea, the following discussion will focus on the structure, function and productivity of the copepod community at a more general level, taking an overall life strategy and functional approach.

\section{Contribution of different groups of copepods to overall biomass and production}

The use of $200 \mu \mathrm{m}$ nets recommended by UNESCO (1968) for sampling of copepods unfortunately still biases our knowledge about copepods. The available literature primarily addresses the role of the larger calanoid copepods in the marine environment. Recently, studies in which appropriate sampling gear has been used (i.e. with mesh size $\leq 50 \mu \mathrm{m}$ ) have documented the importance of small copepods in temperate (Nielsen \& Sabatini 1996, Nielsen \& Andersen 2002), subtropical (Paffenhöfer 1993) and especially tropical seas (Webber \& Roff 1995a,b, Böttger-Schnack 1996). Comparisons of the obtained size spectra of copepods sampled with different gear during the present investigation clearly illustrate the potential bias for interpreting the role of copepods if inappropriate sampling gear is used (Fig. 5). In the Andaman Sea, small copepods, mainly cyclopoids and poecilostomatoid (dominated by Oithona spp. and Oncaea spp.), made up half of the number and ca. $25 \%$ of the copepod biomass. Similar observations were made off Discovery Bay, Jamaica, where Oithona and Oncaea also were among the most important genera (Webber \& Roff 1995a, Hopcroft et al. 1998a).

The importance of egg-carrying species in the Andaman Sea copepod community stresses the significance of this life strategy in tropical oligotrophic ecosystems (Hopcroft et al. 1988a, Chisholm \& Roff 
1990b, Calbet \& Agustí 1999). The relatively high biomass of egg-carrying species, regardless of their significantly lower egg production rate compared to co-occurring broadcast species ( $t$-test, $\mathrm{p}<0.0001)$, indicates an adaptive advantage of this life strategy. The advantages of egg-carrying species vary from lower egg mortality (Kiørboe \& Sabatini 1994) to lower metabolic demand (Lampit \& Gamble 1982), and to behavioral adaptations that reduce predation (Paffenhöfer 1993). While little is known about egg mortality and metabolic demand of tropical copepods, some information on behavioral adaptations that can reduce predation is available for the 3 important genera of eggcarrying species, Microsetella, Oncaea and Oithona.

Such adaptations include colonization of surfaces and reduction of jump frequencies. Examples of surface-associated species include the genus Microsetella, which is often associated with the large colonial cyanobacterium Trichodesmium (Dagg \& Green 1994, Roman et al. 2000, Landry et al. 2001, T.G.N. pers. obs.) and Oncaea spp., which are often found on and in aggregates and houses of appendicularians (Aldredge 1972). Both of these habitats may reduce the predation risk significantly. The swimming behavior of the cyclopoid Oithona, with much lower jump frequency than the continuously swimming calanoids, reduces its vulnerability to predators by only rarely producing signals to potential predators (Paffenhöfer 1993).

Rates of egg production by free spawning copepod species are routinely used to estimate copepod production in the field (e.g. McLaren \& Corkett 1981, Saiz et al. 1997), assuming that adult females do not grow, but rather allocate the ingested carbon into the production of eggs (Berggreen et al. 1988). While the SEP of broadcast spawning copepods is generally estimated from $24 \mathrm{~h}$ incubation of females, this method cannot be directly applied to egg-carrying species that typically produce clutches of eggs which they carry for several days. In the present study, the egg production rates of egg-carrying copepods were measured in parallel with the free-spawning calanoid copepods from experimentally determined hatching rates (Table 7) and in situ egg:female ratios. No response in egg production rate was observed for any of the 2 life strategies in association with the shelf break or between the 2 monsoon seasons. In temperate and arctic ecosystems, egg production of the cyclopoid Oithona spp. was much less variable in time and space than the co-occurring calanoid copepods (Kiørboe \& Nielsen 1994, Nielsen \& Sabatini 1996). The free spawning calanoids are more opportunistic and ready to exploit small pulses in the prey field (Tester \& Turner 1990), while the production of the egg carriers is integrated over a longer period of time, leading to a less opportunistic life strat- egy (Kiørboe \& Sabatini 1994, Nielsen \& Sabatini 1996). This difference in the variability of egg production rates was also observed in the Andaman Sea, where variability was higher for the free-spawners compared to the egg-carrying spp. (Table 6).

\section{Can copepod egg production rate be used to estimate community growth and ingestion rates?}

The central assumption behind the egg production method is that the weight-specific egg production rate (SEP) is equal to the growth rate of the younger stages (Berggreen et al. 1988). If so, total copepod production can be estimated from SEP and the standing stock. This assumption has been verified for calanoid copepods in eutrophic temperate waters (Sekiguchi et al. 1980, Berggreen et al. 1988, Fryd et al. 1991). In more oligotrophic waters, however, juvenile stages are less food-limited that the copepod adults (Webber \& Roff 1995a,b, McKinnon 1996, Hopcroft \& Roff 1998b). On the other hand, when resources are not limiting, growth rates may be approximately constant across all development stages and comparable to the weightspecific egg production rate (Fryd et al. 1991, Hopcroft \& Roff 1998b), and egg production can be used as measure of production of the entire copepod community.

In the Andaman Sea, females of the various species considered contributed 46 to $61 \%$ of the biomass (Table 11), illustrating that our production and grazing calculations are representative for the majority of the copepod community standing stock. However, since the egg production rate of the Andaman Sea copepods was clearly food limited, an obvious question arises regarding the potential bias of our production estimate when SEP is assumed to be the growth rate of the entire community.

Off Jamaica, Hopcroft \& Roff $(1998 \mathrm{a}, \mathrm{b})$ compared copepod production estimates calculated from (1) direct measurement of naupliar and copepodite somatic growth and SEP, and (2) application of SEP to all stages. At the eutrophic Kingston Habour (1.75 $\mu \mathrm{g}$ chl a $\mathrm{l}^{-1}$ ), SEP underestimated production by $40 \%$,

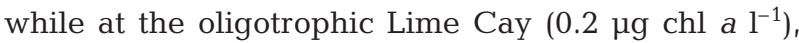
comparable to the Andaman Sea, the deviation was more pronounced. Here the SEP gave $260 \%$ less production that the estimate considering the growth rate of the specific stages.

To evaluate the potential bias of our application of SEP to the entire copepod population, we recalculated our production values using data from Lime Cay off Jamaica comparable to the Andaman Sea. Average calanoid and cyclopoid growth rates of nauplii and copepodites originate from Table 1 in Hopcroft \& Roff (1998b) and Table 1 in Hopcroft et al. (1998b), respec- 
Table 11. Female contribution to the total biomass $(\%$; mean $\pm \mathrm{SE}, \mathrm{n})$ of the copepod species along the middle transect during 3 cruises in the Andaman Sea

\begin{tabular}{|lcccc|}
\hline & SW-96 & NE-97 & SW-97 & All cruises \\
\hline Acrocalanus gibber & $44.1 \pm 5.2,10$ & $43.9 \pm 3.7,13$ & $46.0 \pm 7.2,9$ & $44.5 \pm 2.9$ \\
Acartia australis & $41.2 \pm 12.5,4$ & $55.8 \pm 6.0,10$ & & $56.6 \pm 5.6$ \\
Centropages furcatus & $44.3 \pm 3.5,7$ & $47.1 \pm 5.7,10$ & $46.5 \pm 6.2,6$ & $46.1 \pm 3.0$ \\
Temora discaudata & $33.7 \pm 5.4,5$ & $61.3 \pm 5.2,11$ & $47.8 \pm 9.7,4$ & $51.7 \pm 4.4$ \\
Euchaeta marinella & $45.1 \pm 9.6,8$ & $50.9 \pm 6.5,10$ & $46.1 \pm 5.7,8$ & $47.6 \pm 4.1$ \\
Oncaea venusta & $57.6 \pm 4.1,9$ & $44.6 \pm 3.1,13$ & $61.6 \pm 2.8,9$ & $53.3 \pm 2.3$ \\
Oithona plumifera & $70.5 \pm 3.9,10$ & $54.7 \pm 4.3,13$ & $58.9 \pm 4.2,9$ & $60.8 \pm 2.6$ \\
& & & & \\
\hline
\end{tabular}

Table 12. Comparison of copepod biomass, productivity and turnover rates in tropical marine waters. EM: empirical model; *estimated from the measured SEP and growth rates of nauplii and copepodites from Jamaica from Hopcroft \& Roff (1998b) and Hopcroft et al. (1998b), respectively

\begin{tabular}{|c|c|c|c|c|c|c|}
\hline Areas & $\begin{array}{l}\text { Integration } \\
\text { depth }(\mathrm{m})\end{array}$ & $\begin{array}{l}\text { Biomass } \\
\left(\mathrm{mg} \mathrm{C} \mathrm{m}^{-2}\right)\end{array}$ & $\begin{array}{l}\text { Productivity } \\
\left(\mathrm{mgC} \mathrm{m}^{-2} \mathrm{~d}^{-1}\right)\end{array}$ & Production measured from & $\begin{array}{l}\mathrm{P} / \mathrm{B} \\
\left(\mathrm{d}^{-1}\right)\end{array}$ & Source \\
\hline Zanzibar, coastal & 22 & $100 \pm 13$ & $88 \pm 10$ & EM by Huntley \& Lopetz (1992) & 0.88 & Lugomela et al. (2001) \\
\hline Jamaica neritic & 20 & 50 & $\sim 35$ & EM by Middlebrook \& Roff (1986) & 0.75 & Chisholm \& Roff $(1990 a, b)$ \\
\hline \multirow[t]{2}{*}{ Jamaica oceanic } & 60 & 55 & $\sim 11$ & $*$ & 0.2 & Webber \& Roff $(1995 a, b)$ \\
\hline & 200 & 96 & $\sim 20$ & $*$ & 0.2 & - \\
\hline Hawaii & 150 & 286 & 25 & EM by Hirst \& Lampit (1998) & 0.09 & Roman et al. (2002) \\
\hline Bermuda & 150 & 137 & 10 & EM by Hirst \& Lampit (1998) & 0.07 & Roman et al. (2002) \\
\hline Arabian Sea & 200 & 1320 & 156 & EM by Hirst \& Sheader ( 1997 ) & 0.12 & Roman et al. (2000) \\
\hline Andaman Sea & 100 & $381 \pm 28$ & $\begin{array}{c}23 \pm 2 \\
115 \pm 10^{*}\end{array}$ & Calculated from SEP & $\begin{array}{l}0.06 \\
0.30^{*}\end{array}$ & This study \\
\hline
\end{tabular}

tively. The application of the Jamaica growth rates for juvenile stages gave a 5-times higher production than the estimates based on SEP alone. However, although the 2 areas seem comparable, the SEP of females off Jamaica (Hopcroft \& Roff 1998a) were also significantly higher for calanoids $(0.15 \pm 0.04$ compared to our $0.06 \pm 0.01$ ) and for the cyclopoid Oithona plumifera (0.38 compared to our $0.05 \pm 0.01)$, indicating that Lime Cay in general is more productive. On the other hand, there is no doubt that our copepod production rates for the oligotrophic Andaman Sea are underestimated by not considering the fast growing smaller stages separately.

In the present study, copepod secondary production based on SEP was estimated to vary from 3 to $93 \mathrm{mg} \mathrm{C}$ $\mathrm{m}^{-2} \mathrm{~d}^{-1}$ during 3 cruises, with an average of $23 \pm 2 \mathrm{mg}$ $\mathrm{C} \mathrm{m}^{-2} \mathrm{~d}^{-1}$ (Table 8). Calanoids contributed most (64.3 \pm $6.5 \%)$, followed by cyclopoids and poecilostomatoid $(10.6 \pm 1.0 \%)$ and harpacticoids $(2.5 \pm 0.5 \%)$. In general, the integrated biomass was within the range measured in similar environments (Table 12). The copepod production, however, was substantially lower than reported for the other areas primarily due to the low $\mathrm{P}: \mathrm{B}$ ratio when SEP is used, indicating that growth rates of the smaller stages should be considered. If the Jamaica estimates of nauplii and copepodite growth were applied to the Andaman Sea community, the estimated production would be comparable to that of other areas.

\section{Is copepod production in the Andaman Sea food limited?}

The average chl a concentration in the Andaman Sea during the present investigation (0.19 to $0.4 \mu \mathrm{g} \mathrm{chl} \mathrm{a} \mathrm{l}^{-1}$ corresponding to 10 to $20 \mu \mathrm{g} \mathrm{C} \mathrm{l}^{-1}$ ) was far below saturation level of copepod clearance, indicating that the growth rate of the copepod community was food limited (Hansen et al. 1997). Knowledge about egg production potential of tropical marine copepods is, however, very limited; the highest values measured in our investigation are lower than the few available rates from other more eutrophic warm water ecosystems (Mckinnon 1996, Hopcroft \& Roff 1998a), illustrating that the egg production rate is limited by potential food. In a much-debated paper, Huntley \& Lopez (1992) state that temperature alone can explain $>90 \%$ of the growth rates of copepods, and that food may not be limiting to growth in nature. They suggested a temperature-dependent model for the estimation of copepod secondary production. The above hypothesis 
can be tested by applying the equation of Huntley \& Lopez (1992), $\mathrm{P}=\mathrm{B} \cdot 0.0445 \mathrm{e}^{0.111 \mathrm{~T}}$, where $\mathrm{P}=$ production, $\mathrm{B}=$ biomass and $\mathrm{T}=$ temperature, to our biomass data and the average temperature of each station. This results in production which is 18 times higher than the actual production obtained from our study. Despite the previously mentioned potential underestimation of production by the use of SEP to calculate community production, this shows that the temperature-dependent method suggested by Huntley \& Lopez (1992) cannot be applied to the tropical Andaman Sea. Consequently temperature alone cannot be used as the control function of copepod growth and production. The results corroborate that the copepod community in the Andaman Sea was strongly food limited. The data that support the Huntley \& Lopez hypothesis come mainly from arctic and temperate areas, and relatively few are from areas where the temperature exceeds $20^{\circ} \mathrm{C}$. The few data points for areas with higher temperatures are from studies of productive eutrophic ecosystems (e.g. estuaries and upwelling areas), and not warm oligotrophic ecosystems, which characterize most subtropical and tropical seas (Calbet \& Agustí 1999).

\section{Trophic role of copepods in the Andaman Sea food web}

The fate of primary production in the pelagic food web strongly depends on the size composition of the phytoplankton. The primary producers in oligotrophic tropical oceans are typically dominated by picoplankton (Campbell et al. 1997), which are not directly available to copepods (Hansen et al. 1994, Calbet et al. 2000). In the Andaman Sea, phytoplankton size distribution is bimodal with cells $>50$ or $<1 \mu \mathrm{m}$ (Fig. 5). Consequently, the copepod community has, to a large extent, to rely on an amplification of the average prey size through the microbial food web. During the NE-97 cruise, phytoplankton $>10 \mu \mathrm{m}$ only contributed ca. $33 \%$ to the potential prey population available to the copepods (phytoplankton $>10 \mu \mathrm{m}+$ protozooplankton), stressing the potential importance of microprotozooplankton as food for the copepod community. The actual available phytoplankton biomass may indeed be much lower, especially in the surface water, because of the filamentous cyanobacterium Trichodesmium, which is often a major component of the phytoplankton $>10 \mu \mathrm{m}$ (contributing $11 \pm 8 \%$ at the FM and $32 \pm 18 \%$ at $5 \mathrm{~m}$ to total biomass). The low availability of the dominating phytoplankton for the copepods stresses the need of alternative food sources, the most obvious being the protozooplankton, i.e. ciliates and heterotrophic dinoflagellates.
Unfortunately, the few measurements of energy flow through the tropical pelagic food web is a considerable obstacle for understanding the function of these globally important areas. Nonetheless, as a first attempt to illustrate the fate of the pelagic production in the Andaman Sea, we have established carbon flux budgets for the 3 identified regions along the studied transects, taking into account the observed variability in rates and distributions (Fig. 13). Assuming that adult copepods are not able to ingest the dominating primary producers directly (Hansen et al. 1994, Calbet et al. 2000), the protozooplankton play a key role in the transfer of energy up the food chain. The grazing rates of the heterotrophic dinoflagellates and ciliates were estimated assuming maximum clearance and a $Q_{10}$ of 2.8 from the equation in Hansen et al. (1997). From the calculated ingestion rates, protozooplankton production was estimated assuming a growth yield of $33 \%$ (Hansen et al. 1997). The carbon need of the copepod community was estimated as biomass multiplied by SEP, also assuming a growth yield of $33 \%$. This crude calculation shows that copepods ingest, on average, less than $19 \%$ of their total biomass daily, $\sim 71 \mathrm{mg} \mathrm{C} \mathrm{m}{ }^{-2} \mathrm{~d}^{-1}$. We may well have underestimated the copepod production, using the egg production method as discussed above, by a factor of ca. 2 to 3 . If so, the copepod community also have to exploit the small primary producers directly (Fig. 13). However, this simple calculation highlights the potential role of the microbial food web in an oligotrophic tropical marine ecosystem. Nevertheless, there is a strong need for more direct information about the trophic coupling between copepods and protozooplankton in picoplankton-dominated marine systems.

\section{CONCLUSIONS}

Regardless of the high spatial resolution of sampling across of the very dynamic shelf, no zone of particularly high primary (Nielsen et al. 2004) or secondary production could be identified (Fig. 13). Consequently, the hypothesis suggested by previous investigators, that the shelf break in the Andaman Sea was particularly productive and should fuel a new unexploited fisheries resource (Wium-Andersen 1977, Yesaki \& Jantarapagdee 1981, Kiørboe et al. 1991), could not be confirmed. Indications of enhanced fish larval abundance was observed, however, at the mid-shelf front (50 to $65 \mathrm{~m}$ bottom depth), where the abundance of fish larvae peaked in a zone where the pycnocline meets the sea-bottom and cold nutrient-rich salt water is introduced to the surface layer (Munk et al. 2004). No response in copepod secondary production was observed there. In general, copepod production in the Andaman Sea is rather high (Table 12), despite the 


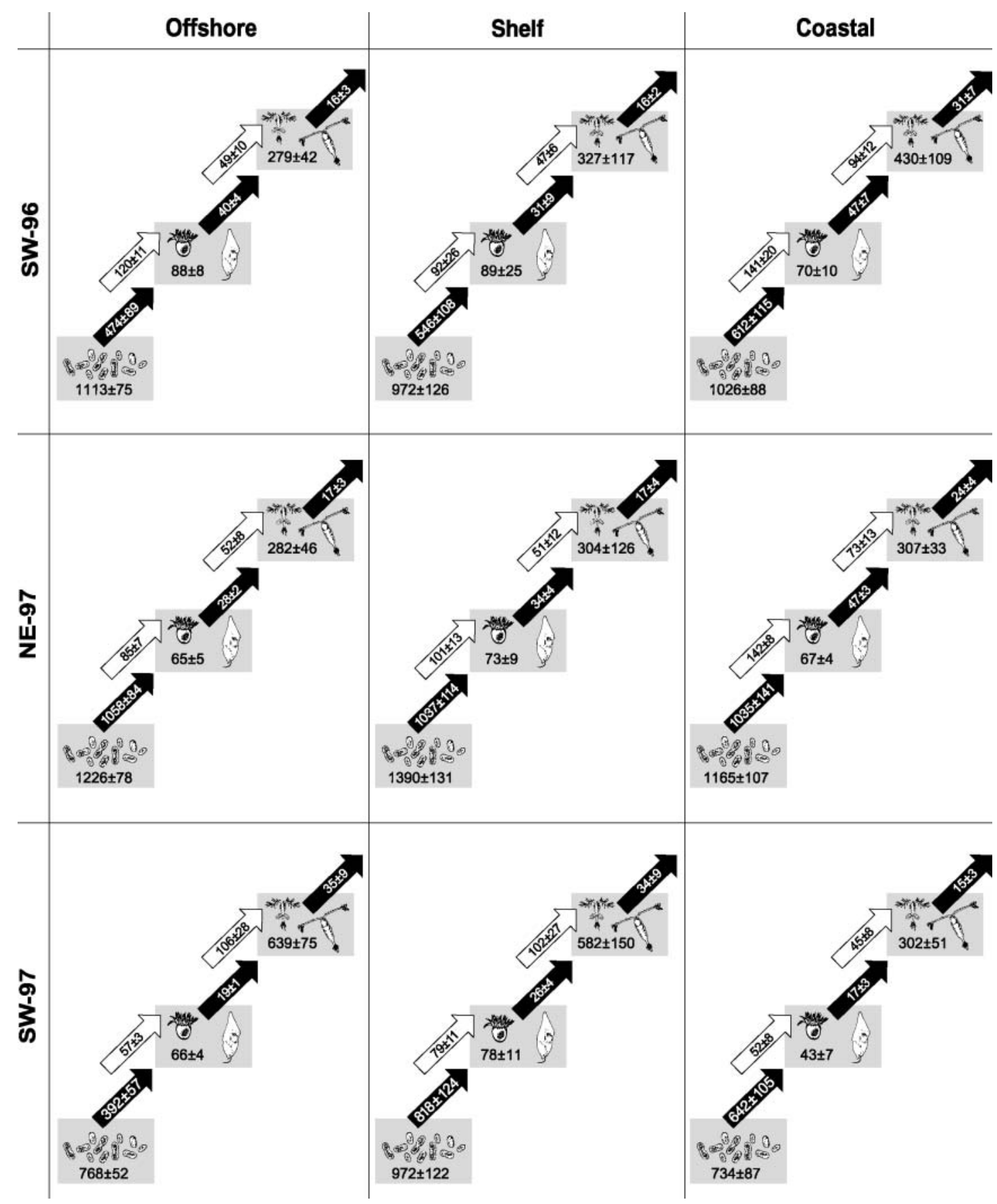

Fig. 13. Carbon-flow diagram of the coastal, shelf and offshore areas during the 3 cruises. Numbers in the boxes illustrate average biomass $\pm \mathrm{SE}\left(\mathrm{mg} \mathrm{C} \mathrm{m}^{-3}\right)$. Arrows represent daily production $\pm \mathrm{SE}$ (black) and ingestion rate $\pm \mathrm{SE}\left(\right.$ white; $\left.\mathrm{mg} \mathrm{C}^{-3} \mathrm{~d}^{-1}\right)$. Primary production originated from Nielsen et al. (2004) and Jarnekarn (unpubl.)

dominance of small primary producers. The relatively high biomass of protozooplankton available to copepods indicates a strong coupling between copepods and the microbial food web. Knowledge about this trophic pathway is very limited and needs to be further elucidated if the dynamics of oligotrophic tropical oceans such as the Andaman Sea are to be understood.
Acknowledgements. We are grateful to all staff of the Marine Biological Productivity Unit, $\mathrm{PMBC}$, and also the crew of RV 'Chrakratong Tongyai' for their assistance with the field work. Ruth Boettger-Schnack, Thomas Kiørboe, Russel R. Hopcroft, Michael R. Landry and Dave McKinnon are acknowledged for constructive comments on an earlier version of the manuscript. Khodeeyoe Pornchai is thanked for her hard work on the biomass samples. Ole Schou Hansen and Christian Marc 
Andersen are thanked for their assistance with sampling and experimental work. This work is supported by Department of Fisheries (Thailand), DANIDA Grant \#104.P.3 Thailand to S.S. and Danish National Research Council Grant \# 9801391 to T.G.N. and P.J.H. This is contribution \#44 of the PMBC.

\section{LITERATURE CITED}

Aldredge AL (1972) Abandoned larvacean houses: a unique food source in the pelagic environment. Science 177: $885-887$

Anon (1997) Fisheries statistics of Thailand No 8/1997. Fisheries Economics Division, Department of Fisheries, Ministry of Agriculture and Cooperatives, Bangkok

Baars MA, Stutotomo AB, Oosterhuis SS, Arinardi (1990) Zooplankton abundance in the Eastern Banda Sea and Northern Arafura Sea during and after the upwelling season, August 1984 and February 1985. Neth J Sea Res 25:527-543

Berggreen U, Hansen B, Kiørboe T (1988) Food size spectra, ingestion and growth of the copepod Acartia tonsa during development: implications for determination of copepod production. Mar Biol 99:341-352

Bhattathiri PMA, Pant A, Sawant S, Gauns M, Matondkar SGP, Mohanraju R (1996) Phytoplankton production and chlorophyll distribution in the eastern and central Arabian Sea in 1994-1995. Curr Sci 71:857-862

Boonruang P (1985) The community structure, abundance and distribution of zooplankton at the east coast of Phuket Island, Southern Thailand, Andaman Sea. Res Bull Phuket Mar Biol Cent 39:1-13

Böttger-Schnack R (1996) Vertical structure of small metazoan plankton, especially non-calanoid copepods. I. Deep Arabian Sea. J Plankton Res 18:1073-1101

Burkill PH, Mantoura RFC, Owens HJP (1993) Biogeochemical cycling in the Northern western Indian Ocean, a brief overview. Deep Sea Res II: 643-649

Calbet A, Augustí S (1999) Latitudinal changes of copepod egg production rates in Atlantic waters: temperature and food availability as the main driving factors. Mar Ecol Prog Ser 181:155-162

Calbet A, Landry MR, Scheinberg RD (2000) Copepod grazing in a subtropical bay: species-specific responses to a midsummer increase in nanoplankton standing stock. Mar Ecol Prog Ser 193:75-84

Campbell L, Liu H, Nolla HA, Vaulot D (1997) Annual variability of phytoplankton and bacteria in the subtropical North Pacific Ocean at Station ALOHA during 1991 to 1994 ENSO event. Deep Sea Res I 4:167-192

Chisholm LA, Roff JC (1990a) Size-weight relationships and biomass of tropical neritic copepods off Kingston, Jamaica. Mar Biol 106:71-77

Chisholm LA, Roff JC (1990b) Abundances, growth rates, and production of tropical neritic copepods off Kingston, Jamaica. Mar Biol 106:79-89

Dagg MJ, Green EP (1994) Marine snow in the northern Gulf of Mexico. EOS Trans Am Geophys Union 75:36

Edwards ES, Burkill PH, Stelfox ES (1999) Zooplankton herbivory in the Arabian Sea during and after the SW monsoon, 1994. Deep Sea Res II 46:843-863

Fryd M, Haslund OH, Wohlgemouth O (1991) Development, growth and egg production of the two copepod species Centrophage hamatus and Centrophages typicus in the laboratory. J Plankton Res 13:683-689

Garrison DL, Gowing MM, Hughes MP, Campbell L and 11 others (2000) Microbial food web structure in the Arabian Sea: a US JGOFS study. Deep-Sea Res II 47:1387-1422

Gauns M, Mohanraju R, Madhupratap M (1996) Studies on the microzooplankton from the central and eastern Arabian Sea. Curr Sci 71:874-877

Hansen B, Bjørnsen PK, Hansen PJ (1994) Prey size selection in planktonic zooplankton. Limnol Oceanogr 39:395-403

Hansen PJ, Bjørnsen PK, Hansen BW (1997) Zooplankton grazing and growth: scaling within the $2-2000-\mu \mathrm{m}$ body size range. Limnol Oceanogr 42:687-704

Ho JS (1991) Phylogeny of Poecilostomatoida: a major order of symbiotic copepods. Proc 4th Int Conf Copepoda. Bull Plankton Soc Japan Spec Vol. (1991):25-48

Hopcroft RR, Roff JC (1998a) Zooplankton growth rates: the influence of female size and resources on egg production of tropical marine copepods. Mar Biol 132:79-86

Hopcroft RR, Roff JC (1998b) Zooplankton growth rates: the influence of size in nauplii of tropical marine copepodites. Mar Biol 132:87-96

Hopcroft RR, Roff JC, Lombard D (1998a) Production of tropical copepods in Kingston Harbour, Jamaica: the importance of small species. Mar Biol 130:593-604

Hopcroft RR, Roff JC, Webber MK, Witt JDS (1998b) Zooplankton growth rates: the influence of size and resources in tropical marine copepodites. Mar Biol 132:67-77

Huntley ME, Lopez MDG (1992) Temperature-dependent production of marine copepods: a global synthesis. Am Nat 140:201-240

Hygum BH, Rey C, Hansen BW (2000) Growth and development rates of Calanus finmarchicus nauplii duing a diatom spring bloom. Mar Biol 136:1075-1085

Janekarn V, Hylleberg J (1989) Coastal and offshore primary production along the west coast of Thailand (Andaman Sea) with notes on physical-chemical variables. Res Bull Phuket Mar Biol Cent 51:1-20

Jeffrey SW, Humphrey GF (1975) New spectro-photometric equations for determining chlorophylls $a, b, c_{1}$ and $c_{2}$ in higher plants, algae and natural phytoplankton. Biochem Physiol Pflanzen

Kimmerer WJ, McKinnon AD (1987) Growth, mortality, and secondary production of the copepod Acartia tranteri in Westernport Bay, Australia. Limnol Oceanogr 32:14-28

Kiørboe T (1991) Pelagic fisheries and spatio-temporal variability in zooplankton productivity. Bull Plankton Soc Jpn Spec Vol:229-249

Kiørboe T, Nielsen TG (1994) Regulation of zooplankton biomass and production in a temperate, coastal ecosystem. 1. Copepods. Limnol Oceanogr 39:493-507

Kiørboe T, Sabatini M (1994) Reproductive and life cycle strategies in egg-carrying cyclopoid and free spawning calanoid copepods. J Plankton Res 16:1353-1366

Kiørboe T, Janekarn V, Poung-in S, Sawangareeruks S, Piukhao P (1991) New fisheries resources in the Andaman Shelf Sea? Indirect oceanographical evidence. Thai Fish Gazette 44:261-270

Krishnaswami S, Nair RR (1996) JGOFS (India) - Introduction. Curr Sci 71:831-834

Lampitt RS, Gamble (1982) Diet and respiration of the small planktonic copepod Oithona nana. Mar Biol 66:185-190

Landry MR, Al-Mutairi H, Selph KE, Christensen S, Nunnery S (2001) Seasonal patterns of mesozooplankton abundance and biomass at Station ALOHA. Deep Sea Res II 48: 2037-2061

Lebouteiller A, Blanchot J, Rodier M (1992) Size distribution patterns of phytoplankton in the western PacificTowards a generalization for the tropical open ocean. Deep Sea Res 39:805-823 
Legendre L (1981) Hydrodynamic control of marine phytoplankton production: the paradox of stability. In: Nihoul JCJ (ed) Eco-hydrodynamics. Proc 12th Int Liège Colloq Ocean Hydrodynamics. Elsevier, Amsterdam, p 191-207

Levinsen H, Nielsen TG (2002) The trophic role of marine pelagic ciliates and heterotrophic dinoflagellates in arctic and temperate coastal ecosystems: a cross-latitude comparison. Limnol Oceanogr: 47:227-439

Li WKW, Rao DVS, Harrison WG (1983) Autotrophic picoplankton in the tropical ocean. Science 219 (4582): 292-295

Longhurst AL, Pauly D (1987) Ecology of tropical oceans. Acedemic Press, London

Lugomela C, Wallberg P, Nielsen TG (2001) Plankton composition and cycling of carbon during the rainy season in a tropical coastal ecosystem, Zanzibar, Tanzania. J Plankton Res 23:1121-1136

Madhupratap M, Gopalakrishnan TC, Haridas P, Nair KKC, Aravindakshan PN, Padmavati G, Paul S (1996) Lack of seasonal and geographic variation in mesozooplankton biomass in the Arabian Sea and its structure in the mixed layer. Curr Sci 71:863-868

Madsen SD, Nielsen TG, Hansen BW (2001) Annual population development and production by Calanus finmarchicus, C. glacialis and C. hyperboreus in Disko Bay, western Greenland. Mar Biol 139:75-93

Marine Zooplankton Colloquium (2001) Future marine zooplankton research - a perspective. Mar Ecol Prog Ser 222: 297-308

McKinnon AD (1996) Growth and development in the subtropical copepod Acrocalanus gibber. Limnol Oceanogr 41:1438-1447

McLaren IA, Corkett CJ (1981) Temperature-dependent growth and production by marine copepods. Can J Fish Aquat Sci 38:77-83

Middlebrook K, Roff JC (1986) Comparison of methods for estimating annual productivity of the copepods Acartia hudsonica and Eurytemora herdmani in Passamaquoddy Bay, New Brunswick. Can J Fish Aquat Sci 46:656-664

Munk P, Bjørnsen PK, Boonruang P, Fryd M and 9 others (2004) Assemblages of fish larvae and mesozooplankton across the continental shelf and shelf slope of the Andaman Sea (NE Indian Ocean). Mar Ecol Prog Ser 274:87-97

Nielsen TG, Andersen CM (2002) Plankton community structure and production along a freshwater influenced Norwegian fjord system. Mar Biol 141:707-724

Nielsen TG, Sabatini M (1996) Role of cyclopoid copepods Oithona spp. in North Sea plankton communities. Mar Ecol Prog Ser 139:79-93

Nielsen TG, Bjørnsen PK, Boonruang P, Fryd M and 9 others (2004) Hydrography, bacteria and protist communities across the continental shelf and shelf slope of the Andaman Sea. (NE Indian Ocean). Mar Ecol Prog Ser 274:69-86

Osborne AR, Burch TI (1986) Internal solitons in the Andaman Sea. Science 208:451-460

Paffenhöfer GA (1993) On the ecology of marine cyclopoid copepods (Crustacea, Copepoda). J Plankton Res 15: $37-55$

Poung-In S (1992) Biology of the calanoid copepod, Acrocalanus gibber Giesbrecht in the Andaman Sea. Thesis for

Editorial responsibility: Michael Landry (Contributing Editor), La Jolla, California, USA
Master Degree. Graduate School, Chulanognhorn University, Bangkok, p 72

Roman MA, Smith S, Wishner K, Zhang X, Gowing M (2000) Mesozooplankton production and grazing in the Arabian Sea. Deep Sea Res II 47:1423-1450

Roman MR, Adolf HA, Landry MR, Madin LP, Steinberg DK, Zhang X (2002) Estimates of oceanic mesozooplankton production: a comparison using the Bermuda and Hawaii time-series data. Deep Sea Res II 4:175-192

Saiz E, Calbert A, Trepat I, Irigoien X, Alcaratz M (1997) Food availability as a potential source of bias in the egg production methods for copepods. J Plankton Res 19:1-14

Satapoomin S (1999a) Carbon content of some common tropical Andaman Sea. J Plankton Res 21:2117-2123

Satapoomin S (1999b) Zooplankton communities in the Kapur mangrove canal, Ranong Province, Andaman Sea. Res Bull Phuket Mar Biol Cent 62:33-56

Satapoomin S, Pornchai K (2002) Zooplankton communities in Sapam Bay. Res Bull Phuket Mar Biol Cent 64:53-63

Sawant S, Madhupratap M (1996) Seasonality and composition of phytoplankton in the Arabian Sea. Curr Sci 71: 869-873

Schalk PH (1987) Monsoon — related changes in zooplankton biomass in the Eastern Banda Sea and Aru Basin. Biol Oceanogr 5:1-12

Sekiguchi H, McLaren IA, Corcett CJ (1980) Relationship between growth rate and egg production in the copepod Acartia clausi hudsonica. Mar Biol 58:133-138

Smith SL (1982) The northeastern Indian Ocean during the monsoon of 1979: distribution, abundance and feeding of zooplankton. Deep Sea Res 29:1331-1353

Sündstrøm B, Janekarn V, Hylleberg J, Boonruang P (1987) Annual pelagic primary production with notes on physical and chemical variables at Phuket, the Andaman Sea, Thailand. Res Bull Phuket Mar Biol Cent 46:1-18

Suwanrumpha W (1980a) Zooplankton in the inner Gulf of Thailand. I. Seasonal abundance and distribution of zooplankton 1975-1976. Tech Rep No 22/6. Marine Fisheries Laboratory, Dept of Fisheries, Bangkok

Suwanrumpha W (1980b) Zooplankton in the inner Gulf of Thailand. II. Species group and seasonal variation in the copepod 1975-1976. Tech Rep No 22/7. Marine Fisheries Laboratory, Dept of Fisheries, Bangkok

Tester PA, Turner JT (1990) How long does it take copepods to make eggs? J Exp Mar Biol Ecol 141:169-182

UNESCO (1968) Monograph on oceanographic methodology. No 2. Zooplankton sampling. UNESCO, Paris

Verity PG, Smetacek V (1996) Organism life cycles, predation, and the structure of marine pelagic ecosystems. Mar Ecol Prog Ser 130:277-293

Webber MK, Roff JC (1995a) Annual structure of the copepod community and its associated pelagic environment off Discovery Bay, Jamaica. Mar Biol 123:467-479

Webber MK, Roff JC (1995b) Annual biomass and production of the oceanic copepod community off Discovery Bay, Jamaica. Mar Biol 123:481-495

Wium-Andersen S (1977) Primary production in waters around Surin Islands off the west coast of Thailand. Res Bull Phuket Mar Biol Cent 16:1-4

Yesaki M, Jantarapagdee P (1981) Wind stress and sea temperature changes off the west coast of Thailand. Phuket Mar Biol Cent Res Bull 28:27-41

Submitted: May 15, 2002; Accepted: December 11, 2003

Proofs received from author(s): June 4, 2004 